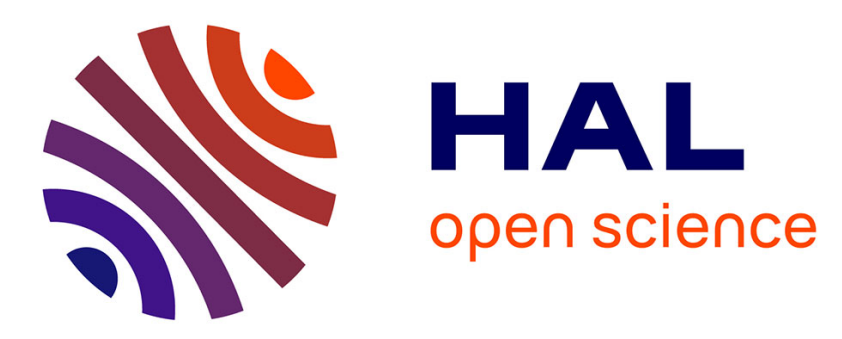

\title{
Tuning the Optoelectronic Properties of Stannoles by the Judicious Choice of the Organic Substituents
}

Isabel-Maria Ramirez y Medina, Markus Rohdenburg, Farzin Mostaghimi, Simon Grabowsky, Petra Swiderek, Jens Beckmann, Jonas Hoffmann, Vincent Dorcet, Muriel Hissler, Anne Staubitz

\section{To cite this version:}

Isabel-Maria Ramirez y Medina, Markus Rohdenburg, Farzin Mostaghimi, Simon Grabowsky, Petra Swiderek, et al.. Tuning the Optoelectronic Properties of Stannoles by the Judicious Choice of the Organic Substituents. Inorganic Chemistry, 2018, 57 (20), pp.12562-12575. 10.1021/acs.inorgchem.8b01649 . hal-01889801

\section{HAL Id: hal-01889801 https://hal.science/hal-01889801}

Submitted on 9 Oct 2018

HAL is a multi-disciplinary open access archive for the deposit and dissemination of scientific research documents, whether they are published or not. The documents may come from teaching and research institutions in France or abroad, or from public or private research centers.
L'archive ouverte pluridisciplinaire HAL, est destinée au dépôt et à la diffusion de documents scientifiques de niveau recherche, publiés ou non, émanant des établissements d'enseignement et de recherche français ou étrangers, des laboratoires publics ou privés. 


\section{Tuning the Optoelectronic Properties of Stannoles}

\section{by the Judicious Choice of the Organic Substituents}

Isabel-Maria Ramirez y Medina ${ }^{* \|}$, , Markus Rohdenburg ${ }^{*}$, , Farzin Mostaghimi ${ }^{\S} \|$, Simon Grabowsky ${ }^{\xi \|}$, Petra Swiderek ${ }^{*} \|$, Jens Beckmann ${ }^{\xi} \|$, Jonas Hoffmann ${ }^{\dagger} \|$, Vincent Dorcet $\perp$, Muriel Hissler $\perp^{\text {, Anne Staubitz }}{ }^{\square} \|^{*}$

$\dagger$ University of Bremen, Institute for Organic and Analytical Chemistry, Leobener Str. 7, 28359 Bremen, Germany

|| University of Bremen, MAPEX Center for Materials and Processes, Bibliothekstr. 1, 28359 Bremen, Germany

†niversity of Bremen, Institute for Applied and Physical Chemistry, Leobener Str. 7, 28359 Bremen, Germany

$\S$ University of Bremen, Institute of Inorganic Chemistry and Crystallography, Leobener Str. 3 and 7, 28359 Bremen, Germany

$\perp$ Univ Rennes, CNRS, ISCR - UMR 6226, F- 35000 Rennes, France, Campus de Beaulieu, 263 Av. du Général Leclerc, 35042 Rennes France

University of Kiel, Otto-Diels-Institute for Organic Chemistry, Otto-Hahn-Platz 4. 24118 Kiel, Germany. 
Stannoles are organometallic rings in which the heteroatom is involved in a form of conjugation that involves excited states $\left(\sigma^{*}-\pi^{*}\right.$-conjugation). Only little is known about how the substituents on the tin atom or substituents on the stannole ring determine the optoelectronic properties of these heterocycles. In this work, this has been studied experimentally and theoretically. Calculations of optimized equilibrium geometries, energy gaps between the HOMOs and LUMOs, and of the absorption spectra of a wide range of compounds were performed. The computational data showed that the substituents on the tin atom influence the optoelectronic properties to a lower extent than the substituents in the 2- and 5-positions of the ring. These substituents in the plane of the stannole ring can also have a strong influence on the overall planarity of the structure, in which mesomeric effects can play a substantial role only if the structure is planar. Thus, only structures with a planar backbone are of interest in the context of tuning optoelectronic properties. These were selected for the experimental studies. Based on this information, a series of six novel stannoles was synthesized by formation of a zirconium intermediate and subsequent transmetalation to obtain the tin compound. The calculated electronic HOMO-LUMO gaps varied between $2.94 \mathrm{eV}$ and $2.68 \mathrm{eV}$. The measured absorption maxima were located between $415 \mathrm{~nm}$ and $448 \mathrm{~nm}$ as compared to theoretically calculated values ranging from $447 \mathrm{~nm}(2.77 \mathrm{eV})$ to $482 \mathrm{~nm}(2.57 \mathrm{eV})$. In addition to these optical measurements, cyclic voltammetry data could be obtained, which show two reversible oxidation processes for three of six stannoles. With this study, it could be demonstrated how the judicious choice of substituents can lead to large and predictable bathochromic shifts in the absorption spectra.

\section{INTRODUCTION}


Heterocycles with a conjugated $\pi$-system that contain a tin atom in the ring are of substantial fundamental interest because the tin atom changes the electronic structure of the overall system substantially. Although there are examples of systems where the tin atom is involved in a classic aromatic system that obeys the Hückel rule, a different, non-aromatic form of conjugation, the $\sigma^{*}$ $\pi^{*}$-conjugation plays a more dominant role. ${ }^{1-5}$

In the context of attempts of lowering the HOMO-LUMO gaps in materials, bathochromic shifts often are achieved by creating push-pull systems (acceptor-donor-systems) by introducing electron donating and accepting groups on opposite ends of the molecule ${ }^{6-8}$ In semiconducting polymers, often two different heterocycles, one electron rich and one electron deficient are coupled. ${ }^{9-12}$ When other main group elements are introduced, the range of possibilities to lower this gap becomes larger: Strategies involve formally antiaromatic compounds such as boroles, ${ }^{13}$ or phosphole oxides. ${ }^{14-15} \mathrm{BN}$-substitution of (poly)aromatic rings ${ }^{16-17}$ results in compounds that are formally aromatic but whose charge delocalization around the ring is severely impeded by the very polar BN-substitution, which may aide long range delocalization of electrons.

However, using $\sigma^{*}-\pi^{*}$-conjugation as a means for lowering the HOMO-LUMO gap is much less common; this phenomenon can be observed by formally substituting the $\mathrm{sp}^{3} \mathrm{C}$ atom in cyclopentadienes by a heavy group 14 and 15 hetero element.

Tin containing metalloles (Figure 1) are part of heavy group $14(\mathrm{Si}, \mathrm{Ge}, \mathrm{Sn}, \mathrm{Pb})$ cyclopentadiene analogs and were first synthesized in $1959 .{ }^{18}$ 

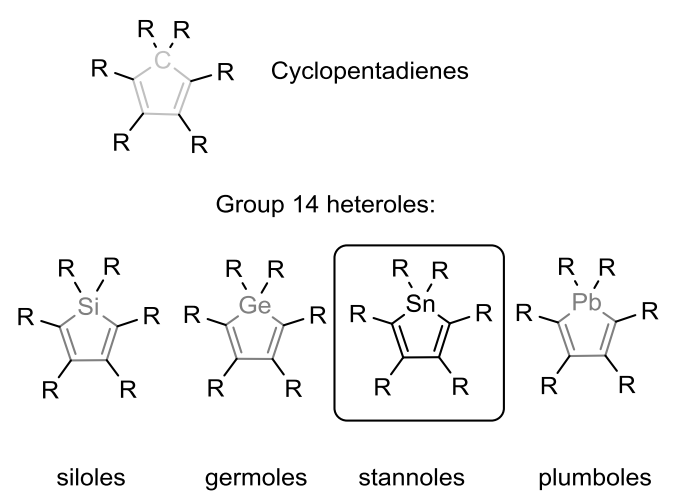

Figure 1. Cyclopentadienes and the related group 14 metalloles.

Since then, investigations of different synthetic routes ${ }^{19-21}$ and studies of the (opto-) electronic properties, ${ }^{22-23}$ aromaticity $^{24}$ and reactivity were conducted for the related siloles, ${ }^{25-27}$ but germoles, ${ }^{28-29}$ stannoles $^{30}$ and plumboles ${ }^{31-32}$ are much less well investigated. ${ }^{33}$ However, the study of such heterocycles is of great interest, since they themselves or their ring fused analogs ${ }^{34-40}$ show great potential in organic electronic devices. ${ }^{41-46}$ The formal replacement of the methylene-C by $\mathrm{Si}, \mathrm{Ge}, \mathrm{Sn}$ or $\mathrm{Pb}$ in cyclopentadiene and its derivatives leads to unique opto-electronic properties in comparison to their carbon analogs. These heteroles show smaller energy gaps between the highest occupied molecular orbital (HOMO) and the lowest unoccupied molecular orbital (LUMO) and a broad bathochromically shifted absorption maximum. Therefore, they are promising building blocks for the development of semiconducting polymers used in organic electronics. ${ }^{47-48}$ The origin of these interesting properties has been well studied by Tamao and co-workers in 1996 and 1998, respectively. ${ }^{22,49}$ Based on quantum chemical calculations, they showed that the replacement of the carbon of the methylene group in cyclopentadiene by $\mathrm{E}=\mathrm{Si}$, Ge or $\mathrm{Sn}$ lowers the energy of the $\sigma^{*}$-orbital of the two exocyclic E-R bonds. This observation results in efficient interactions of the $\sigma^{*}$-orbital and the $\pi^{*}$-orbital of the butadiene moiety (strong $\sigma^{*}-\pi^{*}$-conjugation) compared to the negligibly small $\sigma^{*}-\pi^{*}$-conjugation in cyclopentadiene. This strong $\sigma^{*}-\pi^{*}$-conjugation leads to a remarkable lowering of the LUMO level. ${ }^{22,50}$ A complementary electronic analysis has been 
provided by Ottosson and co-workers on the related siloles. ${ }^{24}$ In this view, the group 14 heteroles can be depicted in several mesomeric forms including ionic forms where the substituent on the tin atom can be anionic or cationic combined with a cationic or anionic heterole counterpart. Depending on the electron withdrawing or donating nature of the substituents on the group 14 heteroatom these mesomeric forms have a higher or lower contribution to the overall energy leading to a bathochromic shift compared to electronically neutral substituents.

Until today, only comparisons of the optoelectronic characteristics of tailored siloles, germoles and their carbon analogs have been reported, but systematic studies of the effects of changing the substituents on stannoles on their optoelectronic properties do not exist. ${ }^{22-23}$ However, such a study is needed, because it could already be demonstrated that stannoles can serve as monomers for conjugated polymers with a strong bathochromic shift as compared to polythiophenes. ${ }^{47-48}$ With a thorough understanding of the electronic characteristics of stannoles, even better optimized desired characteristics may be achievable. In this work, optimized equilibrium geometries of stannoles with different substituents $\mathrm{R}^{1}$ and $\mathrm{R}^{2}$ (Figure 2), their synthesis and comparison of theoretical and experimental absorption maxima is reported. In addition, the electrochemical behavior of six stannoles was analyzed by cyclic voltammetry measurements. Based on these results, the change in the optoelectronic properties by changing the substituents on the tin or the periphery of the molecule can be predicted.

\section{RESULTS AND DISCUSSION}

Initially, a wide range of stannoles was studied theoretically to gain insight into the influence of the different substituents on the tin and in the periphery on the optoelectronic properties (Figure 2). All of those stannoles were substituted with aromatic groups on the tin atom. To draw valid comparisons with the cyclopentadiene analogs, two further stannoles and analogous 
cyclopentadienes were calculated (Figure 3); in those cases, the substituents on the $\mathrm{sp}^{3}$ atom in the ring were methyl groups, because aromatic groups were sterically too large for the cyclopentadienes. Based on these results, a set of six stannoles was selected and synthesized showing that the theoretical calculations were indeed predictive for the experiments.

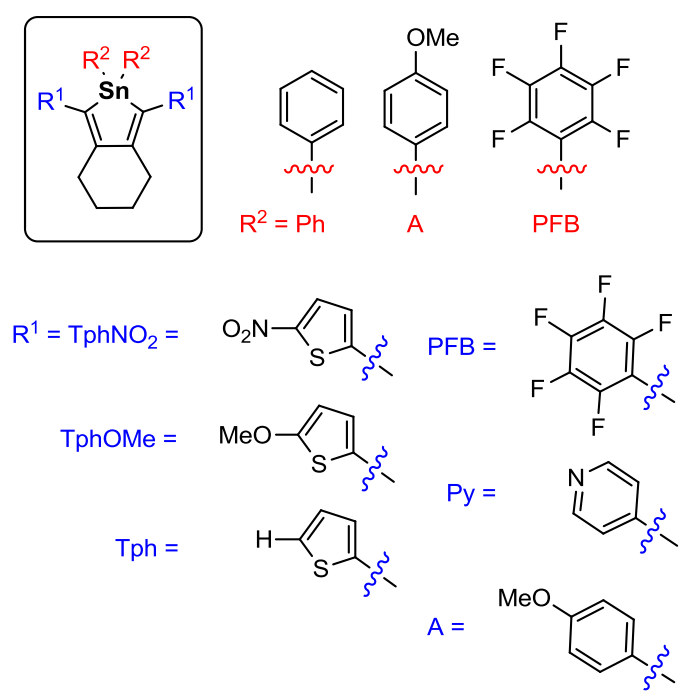

$$
\begin{aligned}
& 1^{*}: R^{1}=T p h, R^{2}=P h \quad 10: R^{1}=P F B, R^{2}=P h \\
& \text { 2*: } R^{1}=T p h, R^{2}=A \quad 11: R^{1}=P F B, R^{2}=A \\
& 3^{*}: R^{1}=\text { Tph, } R^{2}=\text { PFB } \quad 12: R^{1}=P F B, R^{2}=P F B \\
& \text { 4*: } R^{1}=\text { TphOMe, } R^{2}=P h \quad 13: R^{1}=P y, R^{2}=P h \\
& 5^{*}: R^{1}=\text { TphOMe, } R^{2}=A \quad 14: R^{1}=P y, R^{2}=A \\
& \text { 6*: } R^{1}=\text { TphOMe, } R^{2}=\text { PFB } \quad \text { 15: } R^{1}=P y, R^{2}=\text { PFB } \\
& \text { 7: } R^{1}=T_{p h N O}, R^{2}=P h \quad 16: R^{1}=A, R^{2}=P h \\
& \text { 8: } R^{1}=T_{p h N O}, R^{2}=A \quad 17: R^{1}=A, R^{2}=A \\
& \text { 9: } R^{1}=T_{p h N O}, R^{2}=\text { PFB } \quad \text { 18: } R^{1}=A, R^{2}=P F B \\
& \text { 38: } R^{1}=H, R^{2}=P h
\end{aligned}
$$

Figure 2. Stannoles with different substituents $\mathrm{R}^{1}$ and $\mathrm{R}^{2}$ that were investigated by quantum chemical calculations. The compounds indicated with a star* were also synthesized and analyzed experimentally.
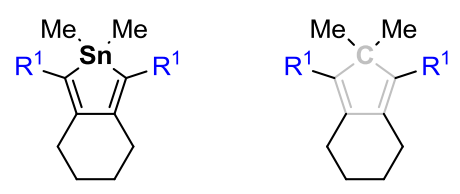
19: $\mathrm{R}^{1}=\mathrm{TphNO}_{2}$ 21: $R^{1}=T p h$
20: $\mathrm{R}^{1}=\mathrm{TphNO}_{2}$ 22: $R^{1}=T p h$ 
Figure 3. Stannoles and the corresponding cyclopentadiene derivatives with methyl substituents on the $\mathrm{sp}^{3}$ atom of the ring.

\section{Optimization of the Selected Structures}

The investigated stannoles fall into two categories: Those with a thiophene derivate in 2- and 5position and those with a six-membered aromatic ring in 2- and 5-position (for two representative structures see Figure 4; for all other structures see the SI). We found that the stannoles with thiophenyl derivatives in the 2- and 5-positions have an overall planar backbone (anti-coplanar arrangement of the thiophenes with respect to the stannole ring), whereas the stannoles with 6membered rings in that position display a twisted backbone (Figure 4). The calculated torsion angle between the thiophene and stannole ring is only $-174.0^{\circ}$ for compound $\mathbf{1}$, whereas in the twisted compound 10, the torsion angle between the fluorinated phenyl group and the stannole is $-123^{\circ}$. The stannole ring is planar in all cases and the substituents on the tin atom are twisted from this plane so that the tin atom has a distorted tetrahedral arrangement.

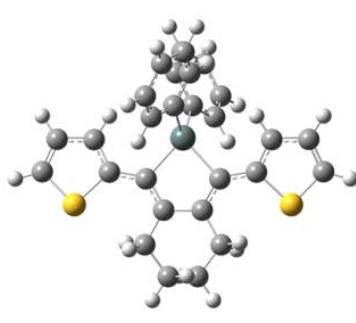

1

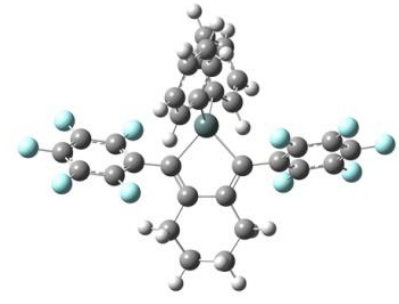

10

Figure 4. Optimized geometries of $\mathbf{1}$ and $\mathbf{1 0 .}$

As the electronic influence for a $\pi$-conjugated system must be much larger for planar backbones than for twisted species, we turned the focus on those stannoles that contain a (substituted) thiophene in the 2- and 5-position.

\section{Molecular Orbital Calculations}


For the theoretical studies of the electronic properties, the orbital energies of the HOMO and LUMO and the resulting energy gaps can be compared (Table 1). 
Table 1. Molecular orbital energies (HOMO-1, HOMO, LUMO and LUMO+1) and HOMO-LUMO gaps (eV).

\begin{tabular}{|c|c|c|c|c|c|c|c|c|c|}
\hline & Molecule & $\mathbf{E}$ & $\mathbf{R}^{1}$ & $\mathbf{R}^{2}$ & $\begin{array}{l}E_{\text {нОмо-1/ }} / \\
\mathrm{eV}\end{array}$ & $\begin{array}{l}E_{\text {номо/ }} \\
\mathrm{eV}\end{array}$ & $\begin{array}{l}E_{\text {LuMo/ }} \\
\mathrm{eV}\end{array}$ & $\begin{array}{l}E_{\text {LUMO+1 }} / \\
\mathrm{eV}\end{array}$ & $\begin{array}{l}E_{\text {gap (номо- }} \\
\text { LUMO)/eV }\end{array}$ \\
\hline & 1 & Sn & Tph & $\mathrm{Ph}$ & -6.38 & -5.00 & -2.07 & -0.82 & 2.93 \\
\hline & 2 & Sn & Tph & $\mathrm{A}$ & -6.11 & -4.93 & -2.00 & -0.54 & 2.93 \\
\hline & 3 & $\mathrm{Sn}$ & Tph & PFB & -6.87 & -5.53 & -2.64 & -2.20 & 2.89 \\
\hline & 4 & $\mathrm{Sn}$ & TphOMe & $\mathrm{Ph}$ & -5.79 & -4.58 & -1.78 & -0.73 & 2.80 \\
\hline & 5 & Sn & TphOMe & $\mathrm{A}$ & -5.74 & -4.52 & -1.72 & -0.46 & 2.80 \\
\hline & 6 & $\mathrm{Sn}$ & TphOMe & PFB & -6.21 & -5.05 & -2.37 & -2.09 & 2.68 \\
\hline & 7 & Sn & $\mathrm{TphNO}_{2}$ & $\mathrm{Ph}$ & -7.45 & -6.18 & -3.85 & -3.17 & 2.33 \\
\hline & 8 & Sn & $\mathrm{TphNO}_{2}$ & A & -6.69 & -6.10 & -3.78 & -3.10 & 2.32 \\
\hline & 9 & $\mathrm{Sn}$ & $\mathrm{TphNO}_{2}$ & PFB & -7.98 & -6.67 & -4.23 & -3.51 & 2.44 \\
\hline & 10 & $\mathrm{Sn}$ & PFB & $\mathrm{Ph}$ & -7.09 & -6.71 & -2.54 & -1.78 & 4.17 \\
\hline & 11 & $\mathrm{Sn}$ & PFB & A & -6.37 & -6.37 & -2.42 & -1.74 & 3.95 \\
\hline & 12 & $\mathrm{Sn}$ & PFB & PFB & -7.97 & -7.33 & -3.19 & -2.45 & 4.14 \\
\hline & 13 & $\mathrm{Sn}$ & Py & $\mathrm{Ph}$ & -6.16 & -6.00 & -2.15 & -0.64 & 3.85 \\
\hline & 14 & $\mathrm{Sn}$ & Py & A & -6.24 & -5.91 & -2.05 & -0.89 & 3.86 \\
\hline & $15^{1}$ & Sn & Py & PFB & - & - & - & - & - \\
\hline & 16 & $\mathrm{Sn}$ & A & $\mathrm{Ph}$ & -5.71 & -5.07 & -1.44 & -0.59 & 3.63 \\
\hline & 17 & Sn & A & A & -5.62 & -5.03 & -1.36 & -0.39 & 3.66 \\
\hline & 18 & Sn & $\mathrm{A}$ & PFB & -6.09 & -5.63 & -2.15 & -1.89 & 3.48 \\
\hline & 19 & $\mathrm{Sn}$ & $\mathrm{TphNO}_{2}$ & $\mathrm{Me}$ & -7.60 & -6.23 & -3.90 & -3.23 & 2.33 \\
\hline & 20 & $\mathrm{C}$ & $\mathrm{TphNO}_{2}$ & $\mathrm{Me}$ & -7.71 & -6.25 & -3.87 & -3.24 & 2.38 \\
\hline & 21 & Sn & Tph & $\mathrm{Me}$ & -6.38 & -4.99 & -2.02 & -0.55 & 2.97 \\
\hline & 22 & $\mathrm{C}$ & Tph & $\mathrm{Me}$ & -6.46 & -4.94 & -1.81 & -0.50 & 3.13 \\
\hline & 38 & $\mathrm{Sn}$ & $\mathrm{H}$ & $\mathrm{Ph}$ & -6.62 & -5.83 & -1.24 & -0.59 & 4.59 \\
\hline
\end{tabular}

${ }^{1}$ Geometry relaxation calculation did not converge so that no minimum geometry could be obtained. 
If we take the unsubstituted stannole $\mathbf{3 8}$ as a point of reference, the energy gap between HOMO and LUMO is much larger than for any of the peripherally substituted stannoles. This gives a first indication that the extension of the conjugated dienyl moiety plays an important role in stannoles. If $\mathrm{R}^{1}$ is changed to a thienyl group (compound $\mathbf{1}$ ), the HOMO increases but the LUMO decreases which results in an overall reduction of the HOMO-LUMO gap by $1.66 \mathrm{eV}$.

A decrease of the HOMO-LUMO gap with an extension of a $\pi$-system is very typical and warrants little discussion. However, the modulation of this effect by the attached $\mathrm{sp}^{3}$ tin atom with its different substituents is interesting and insightful.

For example, in the series 2-1-3 where the substituent on the tin atom becomes increasingly electron deficient with the same substituent in the periphery, both HOMO and LUMO are affected. The energy levels of HOMO and LUMO decrease by ca. $0.5 \mathrm{eV}$, because electron withdrawing groups stabilize the HOMO and LUMO. The same trend can be observed for the series 5-4-6 where the energy levels of HOMO and LUMO decrease also by ca. $0.5 \mathrm{eV}$.

The HOMO-LUMO gap for compounds 1-6 is the lowest in compound $\mathbf{6}$, where the butadienyl system is particularly electron rich because of the attached TphOMe groups and the $\mathrm{R}^{2}$ on the tin particularly electron deficient, creating a push-pull system that operates across the $\mathrm{sp}^{3}$ tin atom.

Although the influence of the substituents on the tin on the overall system is smaller than the $\pi$ system going through the dienyl part of the stannole, the substituents on the tin modulate both HOMO and LUMO. The energy of the HOMO level decreases when there are electronwithdrawing substituents on the tin atom (e.g. perfluorinated phenyl rings, stannoles $\mathbf{3}$ and $\mathbf{6}$ ), but the HOMO level decreases to a higher extent if the electron-withdrawing group is in the periphery (perfluorinated phenyl ring or nitro group at the thiophene, stannoles 7 and 10). 
The isosurface representations of the frontier molecular orbitals show that the HOMO and the LUMO are delocalized over the whole backbone (For representative examples see Figure 5a). The substituents on the tin atom are not involved in the HOMO and only marginally involved in the LUMO. If there are perfluorinated rings on the tin atom as in $\mathbf{3}$ and $\mathbf{6}$, the substituents on the Sn are more involved in the LUMO (see SI). The shapes of the isosurfaces of the HOMO and LUMO orbitals for the compounds 1-3 on the one hand and 4-6 on the other hand are similar (see Figure 5a and SI). If there are 6-membered aromatic rings in the 2- and 5-position, the distribution of the HOMO is much more concentrated on the stannole; the peripheral rings play a smaller role for efficient $\pi$-conjugation as compared to the thiophene rings, because of the ring tilt (Figure 5a). Despite this, electron-withdrawing 6-membered rings do contribute substantially to decreasing the HOMO and LUMO energy presumably mainly by inductive effects. However, a surprising degree of delocalization is found. Because the HOMO is decreased much more than the LUMO (compared to 1), the energy gap between the frontier molecular orbitals is large. If there is a 6-membered ring with electron-donating group in the periphery, for example 16, the HOMO level is increased slightly, but the LUMO level is increased much more strongly. In general, the HOMO-LUMO gaps for the compounds with 6-membered rings in the 2- and 5-position are strongly increased in comparison to these compounds with thiophenes in the 2- and 5-position, but still smaller than for the unsubstituted stannole 38 (Table1). The origin of this observation is likely to be that these substituents are tilted because of steric hindrance with respect to the plane of the stannole (Figure 4). 
a) LUMO
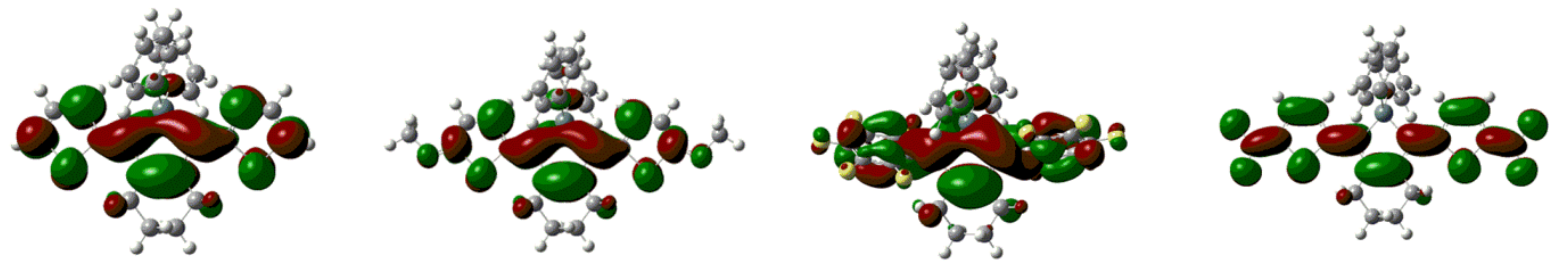

HOMO
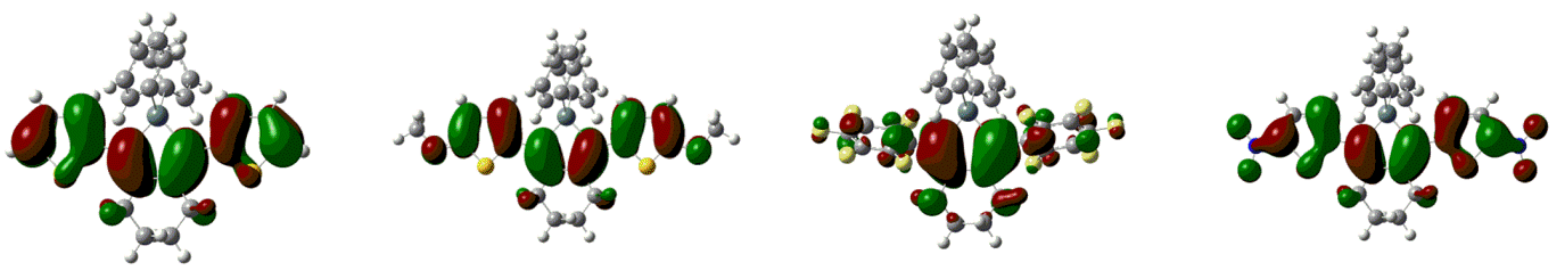

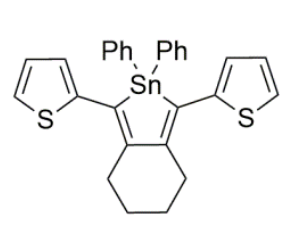

1

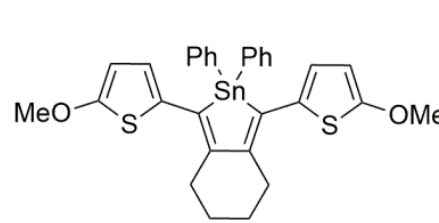

4

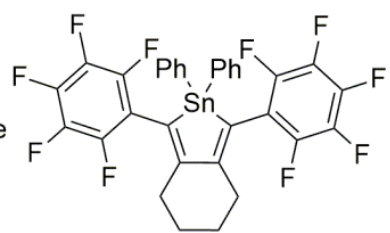

7

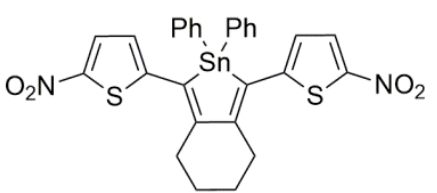

10

b) LUMO

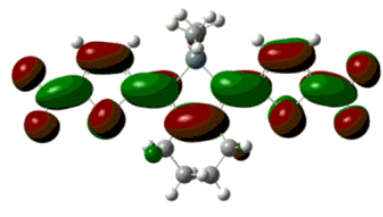

19

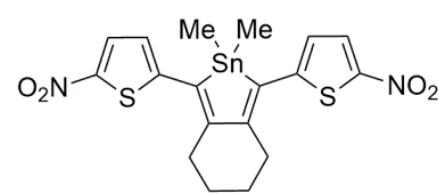

19

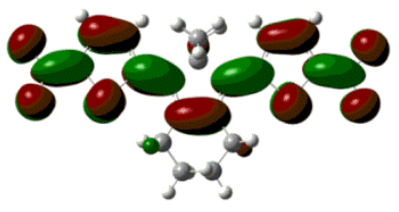

20

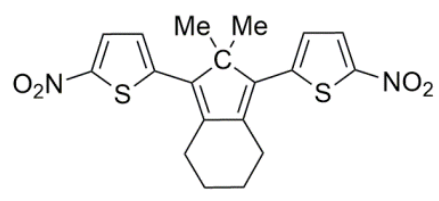

20

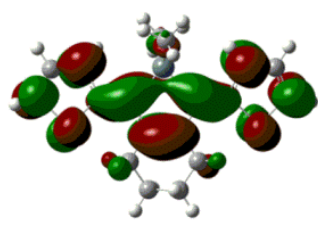

21

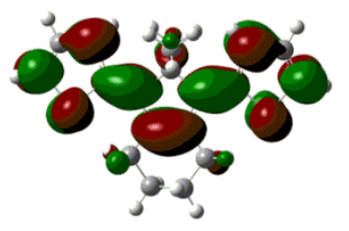

22

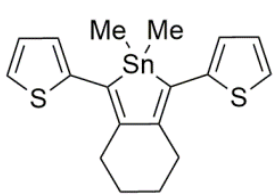

21

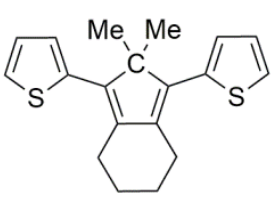

22

Figure 5. a) Isosurface representations of the HOMOs and LUMOs for the stannoles 1, 4, 7 and 10; b) Isosurface representations of the LUMOs of two stannoles and their carbon analogs. 
There was one type of stannole in our study where the tin atom was not at all involved in the LUMO: The stannoles 7-9 with a nitro group attached to the thiophenyl group in the periphery have the narrowest HOMO-LUMO energy gap. A closer inspection of the electronic structure revealed that these systems have a different electronic structure in comparison to stannoles 1-6. In the case of compounds 7-9, the LUMO orbital coefficients are nearly zero on the tin atom, which appears not to be involved in the LUMO (Figure 5a). This means there is no longer the characteristic lobe on the tin, which is responsible for any $\sigma^{*}-\pi^{*}$-conjugation and thus lowering of the $\mathrm{LUMO}^{49}{ }^{49}$ therefore, there should be no difference in the HOMO-LUMO gap between the stannole and its carbon analog. To confirm this hypothesis, we also performed calculations for simplified stannoles 19, 21 and carbon analogs 20, 22 (Table 1, Figure 3). The simplification of using a methyl group instead of a phenyl group on $\mathrm{Sn}$ or $\mathrm{C}$ was necessary, because $\mathrm{C}$ in such cyclopentadienes is too small to accommodate phenyl groups. For Sn-compound 19, the isosurface representation of the LUMO confirms that the tin is no longer involved when there is a nitro group in the 5-position of the thiophene (Figure 5b) and the electronic structure is changed. Sn-compound 21 that contains peripheral thiophenyl groups clearly shows a lobe on the tin and therefore an involvement of the tin atom in the LUMO.

In addition, the energy levels of HOMO and LUMO of these nitro-thiophenyl substituted compounds 19 (Sn-compound) and 20 (C-compound) are almost the same, confirming that the $\mathrm{sp}^{3}$ element in the ring is not part of the $\pi$-system (Table 1). When there are thiophenyl groups in the periphery, the LUMO is lowered in energy for the stannole because of the strong, effective $\sigma^{*}-\pi^{*}$ conjugation resulting in a lower HOMO-LUMO energy gap. The C-analog has no lobe on the $\mathrm{sp}^{3}$ carbon and therefore only a negligibly small $\sigma^{*}-\pi^{*}$-conjugation (Figure 6). 


\section{LUMO}

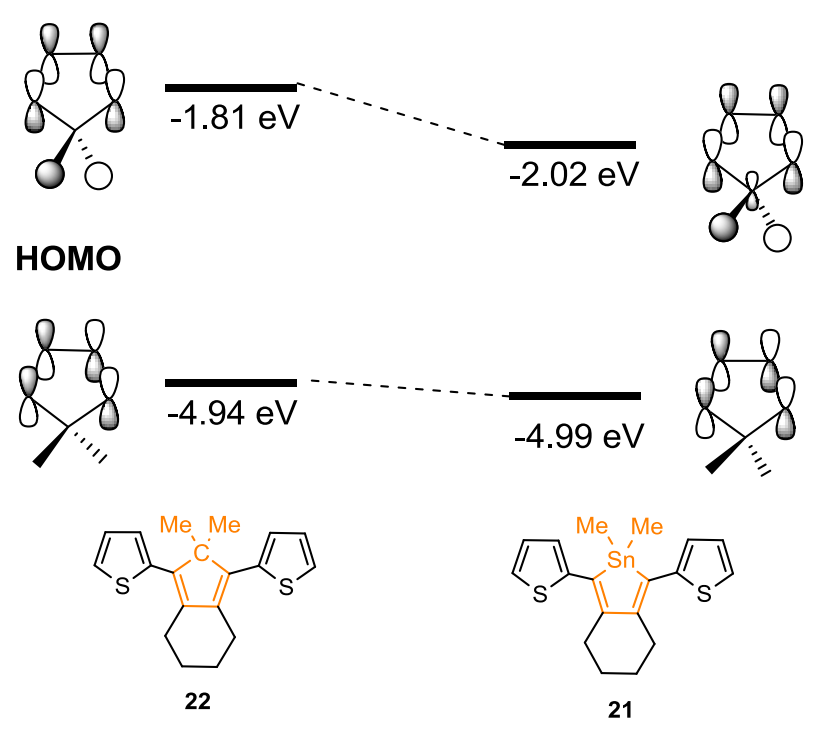

Figure 6. Comparison of the energy levels of HOMO and LUMO between the cyclopentadienederivative 22 and the stannole 21, based on B3LYP/LanL2DZ level of theory; the representation of the orbital levels is simplified based on work by Tamao and co-workers. ${ }^{49}$

The energy levels of the frontier orbitals $+/-1$ allow for additional low-energy electronic excitations if they are energetically close to the HOMO/LUMO levels.

However, according to our calculations (Table 1), these levels contribute only to a minor extent to the intensities of the electronic spectra of the stannoles discussed.

To summarize, the HOMO-LUMO energy gaps appear to be dominated by the substituents in the periphery through $\pi$-conjugation; however, inductive effects play a very important role, which are again higher for the substituents in the periphery. The electronic properties of the molecule may then be fine-tuned by the substituents on the tin atom. It could also be demonstrated for the stannoles that the tin is involved in the LUMO and the origin of the lowered energy level of the LUMO. For these general findings, there was a notable exception: compounds 7-9, which have a different electronic structure. 


\section{Nucleus-Independent Chemical-Shifts (NICS)}

In stannoles, $\sigma^{*}-\pi^{*}$-conjugation is known; and although Ottosson ${ }^{24}$ describes the possibility of some aromatic resonance structures, stannoles are not considered aromatic compounds. The calculated NICS(1) values of the stannoles ranged from -2.74 for compound 2 to -3.25 for molecule 4. For comparison the NICS(1) value for benzene was determined with the same computational method and was found to be -11.26 . Therefore, the stannoles 1-6 only display weak to no aromaticity. Furthermore, only a slight dependence of the NICS(1) values on the substitution pattern of the stannole was observed, which fits with the other experiments reported herein. For a list of all values refer to the SI.

\section{Syntheses}

For the experimental studies, we decided to synthesize the stannoles that have the narrowest HOMO-LUMO gaps and planar backbones, because these are beneficial properties for further potential applications in semi-conducting polymers. Although the stannoles 7-9 also exhibit these characteristics, they were not of our interest for this particular study since the tin atom appears to be not involved in the electronic structure (Figure 5a, b).

The overall synthetic strategy for the stannoles was to form an intermediary zirconium precursor from an adequately substituted octadiyne, followed by transmetalation by a diaryl dichlorostannane.

Different thiophene-flanked octadiynes functioned as precursors for these zirconacyclopentadienes. Electrophilic aromatic substitution of 2-methoxy-thiophene led to compound 25. ${ }^{51-52}$ Twofold Sonogashira cross couplings of 2-iodothiophene or 2-iodo-5methoxythiophene with 1,7-octadiyne gave compounds 26 and 27 with yields of $65 \%$ and 37\% respectively (Scheme 1). 


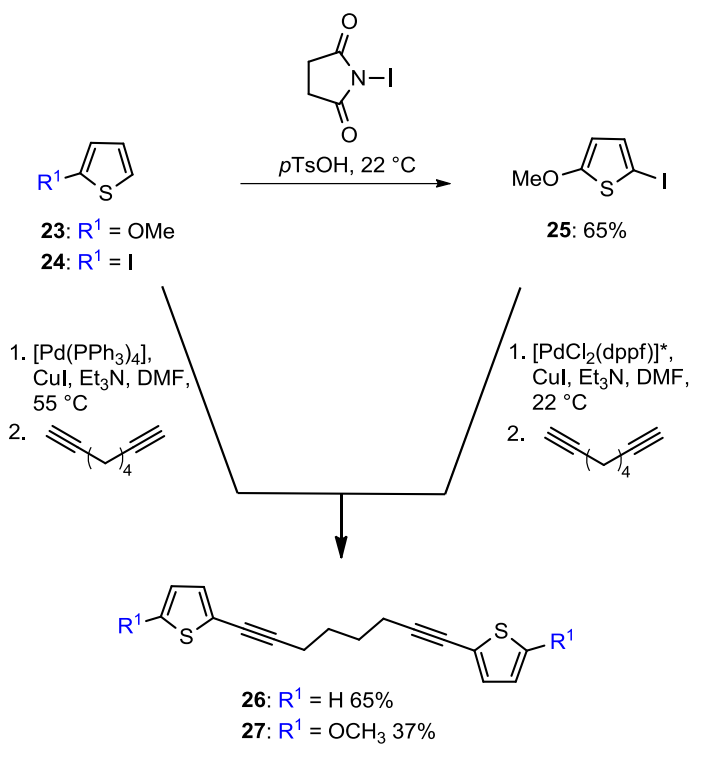

Scheme 1. Synthesis of thiophene-flanked octadiynes; *dppf: 1,1'bis(diphenylphosphino)ferrocene.

Diphenyltin dichloride was obtained commercially, but the diaryltin dichlorides $\mathbf{3 2}$ and $\mathbf{3 3}$ had to be synthesized. Lithiation of pentafluorobenzene (PFB) or 4-bromoanisole (Br-A) and transmetalation to the tin using tin(IV) chloride gave the tetraarylstannanes $\mathbf{3 0}$ and $\mathbf{3 1}$ in yields of $85 \%$ and $97 \%$, respectively. ${ }^{5,53}$ A synproportionation reaction of the tetraarylstannanes $\mathbf{3 0}$ or $\mathbf{3 1}$ at $220-250{ }^{\circ} \mathrm{C}$ for $1-7$ days with tin(IV) chloride led to compounds $32(44 \%)$ and $33(38 \%)$ (Scheme 2). ${ }^{53-54}$ 


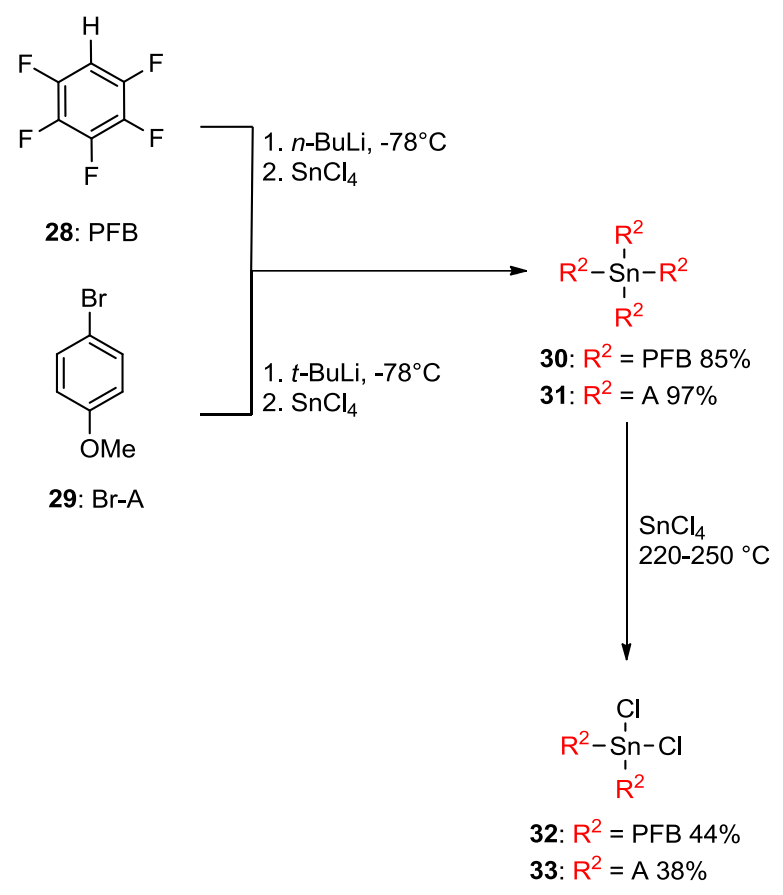

Scheme 2. Synthesis of diaryltin dichlorides.

The formation of the zirconium-intermediates was carried out by the reaction of the precursors 26 or 27 with Rosenthal's zirconocene $34^{55-56}$ in toluene at $20{ }^{\circ} \mathrm{C}$ for $18 \mathrm{~h}$ (Scheme 3) ${ }^{57}$ Full conversion was proven by ${ }^{1} \mathrm{H}$ NMR spectroscopy under inert conditions. The zirconoceneintermediate was directly transformed into the stannole by a consecutive $\mathrm{Zr}-\mathrm{Cu}-\mathrm{Sn}$ exchange reaction with copper (I) chloride as a catalyst and the diaryltin dichlorides $\mathbf{3 2}, \mathbf{3 3}$ or diphenyltin dichloride as reagents within 3 to 6 hours (Scheme 3). In total, six novel stannoles could be provided for the experimental analyses of the theoretical predictions. The stannoles all showed ${ }^{119}$ Sn NMR signals in the range of $-82.4 \mathrm{ppm}$ to $-152.7 \mathrm{ppm}$. 


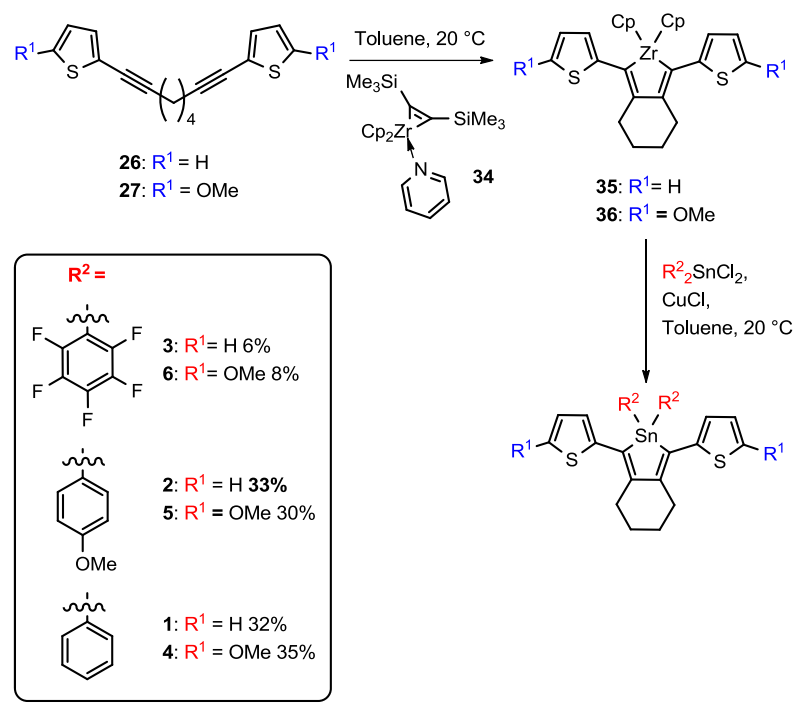

Scheme 3. Synthesis of different stannoles via a zirconocene intermediate.

\section{Crystal Structures}

The molecular structures of $\mathbf{1 , 4}$ and $\mathbf{5}$ are shown in Figure 8 and confirm the identity of the compounds. Compounds $\mathbf{2 , 3}$ and $\mathbf{6}$ were oily products and therefore no crystal structures could be obtained.

The reaction to form stannole $\mathbf{2}$ led not only to the desired product, but also to a by-product $\mathbf{3 7}$, which we could isolate by crystallization. It was identified as a stannole with a spiro-Sn center (Figure 7). The amount in which this by-product was formed was very low $(<2 \%)$ and it is not certain how this compound is formed. Formally, a disproportionation of di- $[p-$ methoxyphenyl]dichlorostannane to $\mathrm{SnCl}_{4}$ and tetra-[p-methoxyphenyl]stannane and subsequent reaction of $\mathrm{SnCl}_{4}$ with two equivalents of the zirconium intermediate $\mathbf{3 5}$ seems likely. However, this would involve a reverse Kocheshkov reaction. While these reactions do take place, they typically require coordinating solvents. ${ }^{58-59}$ 


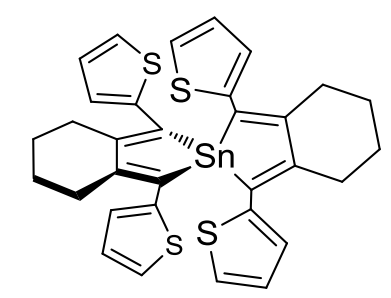

Figure 7. Stannole 37.

In all compounds, the tin atoms were found to be in a tetra-coordinated distorted tetrahedral arrangement. The tin atoms are incorporated into almost planar five-membered central rings, whereas the annulated six-membered rings (the $\mathrm{C}_{4} \mathrm{H}_{8}$ tethers) comprise also puckered confirmations. Selected bond lengths and angles are collected in Table 2. The torsion angles of the planes of the stannoles against the aromatic side groups in 2- and 5-postion of $\mathbf{1 , 4}$ and $\mathbf{5}$ are also compared with the ones of the optimized geometries obtained by DFT calculations. While the structures 1, 4 and $\mathbf{3 7}$ show an overall planarity of the thiophene-stannole backbone with torsion angles $(\mathrm{C}(2)-\mathrm{C}(1)-\mathrm{C}(10)-\mathrm{C}(11))$ of $177.8(2)^{\circ},-177.3(3)^{\circ}$ and $-176.5(5)^{\circ}$ respectively, the thiophenes of compound $\mathbf{5}$ are slightly twisted with respect to the stannole ring with an angle of 161.3(3) ${ }^{\circ}$. The torsion angles of $\mathbf{1}$ and $\mathbf{4}$ agree with the ones of the optimized geometries, but the angle of optimized geometry 5 differs slightly with an angle of $-175.6^{\circ}$. 


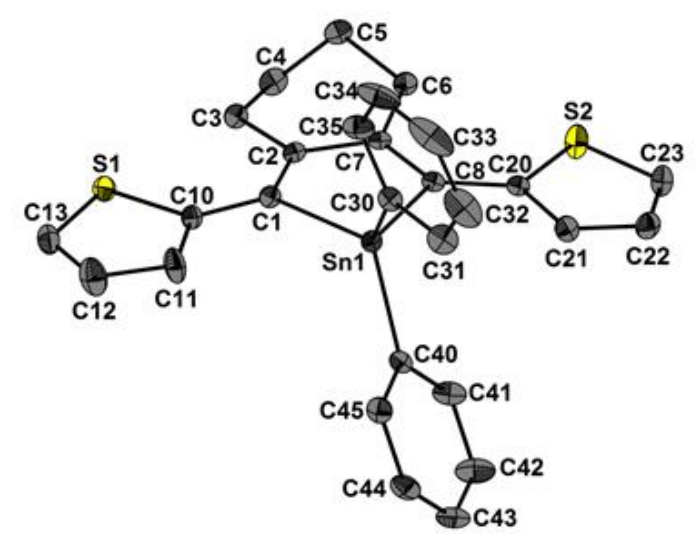

1

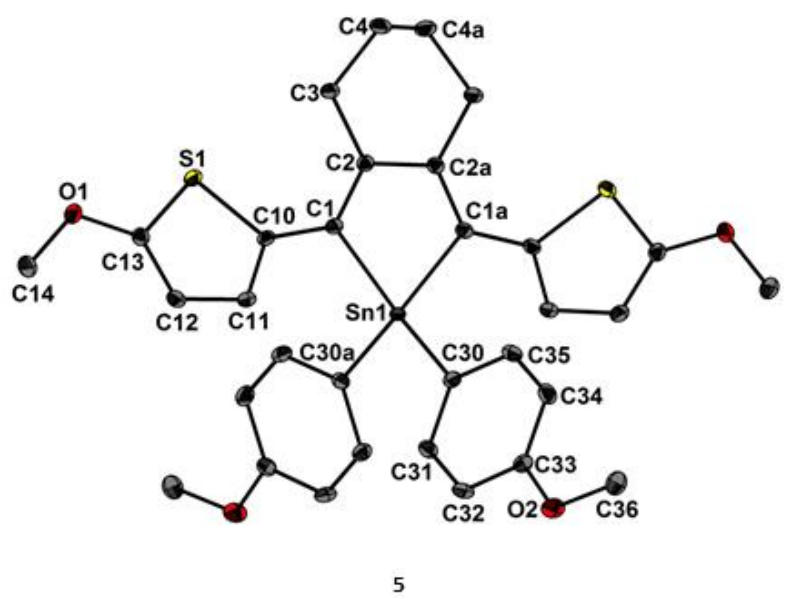

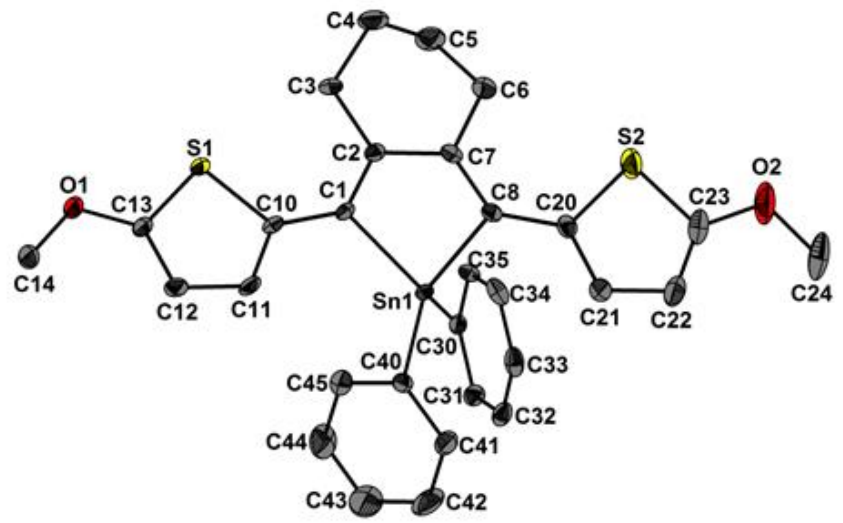

4

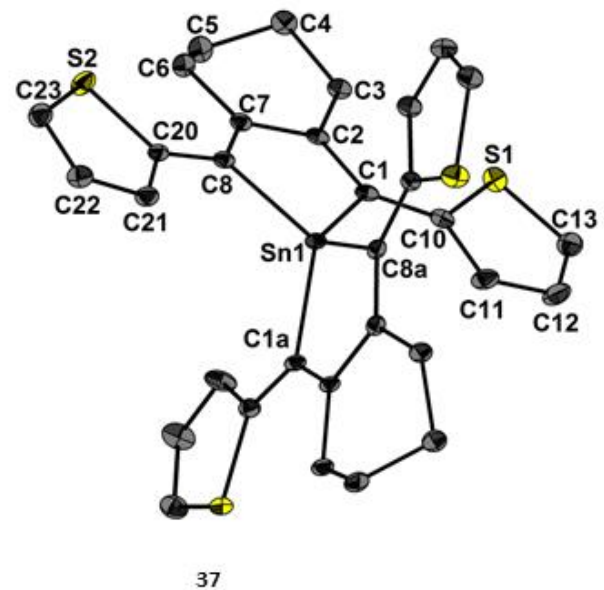

37

Figure 8. ORTEP drawings of the molecular structures of 1, 4, 5 and 37 showing $50 \%$ probability ellipsoids and the crystallographic numbering scheme. 
Table 2. Selected interatomic distances $[\AA]$ and angles $\left[{ }^{\circ}\right]$ of $\mathbf{1}, \mathbf{4}, \mathbf{5}$ and $\mathbf{3 7}$ and comparison of torsion angles with the ones of the calculated structures.

\begin{tabular}{|c|c|c|c|c|}
\hline Compound: & 1 & 4 & 5 & 37 \\
\hline \multicolumn{5}{|c|}{ Bond lengths (in $\AA$ ) and angles (in ${ }^{\circ}$ ) } \\
\hline $\operatorname{Sn}(1)-C(1)$ & $2.149(3)$ & $2.130(2)$ & $2.133(2)$ & $2.133(4)$ \\
\hline $\operatorname{Sn}(1)-C(30)$ & $2.013(3)$ & $2.128(2)$ & $2.123(2)$ & \\
\hline $\operatorname{Sn}(1)-C(40)$ & $2.217(2)$ & $2.128(2)$ & & \\
\hline $\operatorname{Sn}(1)-C(30 a)$ & & & $2.123(2)$ & \\
\hline $\mathrm{C}(1)-\mathrm{C}(2)$ & $1.314(3)$ & $1.368(3)$ & $1.362(3)$ & $1.366(5)$ \\
\hline$C(1)-C(10)$ & $1.498(3)$ & $1.442(3)$ & $1.446(2)$ & $1.441(5)$ \\
\hline $\mathrm{C}(2)-\mathrm{C}(7)$ & $1.561(3)$ & $1.489(3)$ & & $1.496(5)$ \\
\hline$C(2)-C(2 a)$ & & & $1.499(3)$ & \\
\hline$C(1)-\operatorname{Sn}(1)-C(30)$ & $110.73(8)$ & $118.30(8)$ & $118.87(5)$ & \\
\hline$C(1)-\operatorname{Sn}(1)-C(1 a)$ & & & & $124.0(3)$ \\
\hline$C(1)-\operatorname{Sn}(1)-C(40)$ & $122.90(7)$ & $112.99(8)$ & & \\
\hline$C(1)-\operatorname{Sn}(1)-C(30 a)$ & & & $112.42(5)$ & \\
\hline$C(1)-\operatorname{Sn}(1)-C(8 a)$ & & & & $122.8(2)$ \\
\hline$C(30)-\operatorname{Sn}(1)-C(40)$ & $111.38(7)$ & $110.55(9)$ & & \\
\hline$C(30)-\operatorname{Sn}(1)-C(30 a)$ & & & $109.33(7)$ & \\
\hline $\mathrm{Sn}(1)-\mathrm{C}(1)-\mathrm{C}(2)$ & $103.2(2)$ & $108.4(2)$ & 108.93(9) & $108.0(3)$ \\
\hline $\mathrm{C}(1)-\mathrm{Sn}(1)-\mathrm{C}(8)$ & $89.44(7)$ & $83.78(9)$ & & $84.0(3)$ \\
\hline$C(1)-\operatorname{Sn}(1)-C(1 a)$ & & & $83.32(7)$ & \\
\hline $\mathrm{C}(1)-\mathrm{C}(2)-\mathrm{C}(7)$ & $121.6(2)$ & $119.4(2)$ & & $119.7(3)$ \\
\hline $\mathrm{C}(1)-\mathrm{C}(2)-\mathrm{C}(2 \mathrm{a})$ & & & $119.33(8)$ & \\
\hline
\end{tabular}




\begin{tabular}{lllll}
\hline \multicolumn{1}{l}{ Torsion angles in } \\
\hline $\mathrm{C}(2)-\mathrm{C}(1)-\mathrm{C}(10)-\mathrm{C}(11)$ & $177.8(2)$ & $-177.3(3)$ & $-161.3(3)$ & $-176.5(5)$ \\
$\mathrm{C}(1)-\mathrm{C}(2)-\mathrm{C}(7)-\mathrm{C}(8)$ & $8.6(3)$ & $-1.0(4)$ & & $6.3(7)$ \\
$\mathrm{C}(1)-\mathrm{C}(2)-\mathrm{C}(2 \mathrm{a})-\mathrm{C}(1 \mathrm{a})$ & & & $5.2(3)$ & \\
$\mathrm{C}(10)-\mathrm{C}(11)-\mathrm{C}(12)-\mathrm{C}(13)$ & $0.3(4)$ & $0.2(4)$ & $1.7(3)$ & $0.7(7)$ \\
\hline Torsion angles (calculated) in ${ }^{\circ}$ & & & \\
\hline $\mathrm{C}(2)-\mathrm{C}(1)-\mathrm{C}(10)-\mathrm{C}(11)$ & -174.0 & -174.7 & -175.6 & \\
$\mathrm{C}(1)-\mathrm{C}(2)-\mathrm{C}(7)-\mathrm{C}(8)$ & -2.9 & -3.0 & & \\
$\mathrm{C}(1)-\mathrm{C}(2)-\mathrm{C}(2 \mathrm{a})-\mathrm{C}(1 \mathrm{a})$ & & & -3.2 & \\
$\mathrm{C}(10)-\mathrm{C}(11)-\mathrm{C}(12)-\mathrm{C}(13)$ & 0.6 & 0.5 & 0.5 & \\
\hline
\end{tabular}

\section{Theoretical and Experimental Absorption Spectra}

Computational information on the absorption spectrum was obtained for an isolated molecule in the gas phase, while the experimental absorption spectra were measured in chloroform (for calculated and measured spectra of stannoles 1-3 and 4-6 see Figure 9). In general, all theoretical absorption spectra are slightly bathochromically shifted compared to the experimental ones by about $\Delta \lambda_{\max }=26 \mathrm{~nm}$ to $\Delta \lambda_{\max }=32 \mathrm{~nm}$ (Table 3). The shape of the experimental absorption maxima is different from the theoretical ones; the experimental spectra display a shoulder on each side of the maximum. This difference most likely arises because the TD-DFT calculations do not consider vibrational fine structures but only pure electronic transitions. However, the vibrational transitions will also play a role for the characteristic form of absorption bands. Both experimental and theoretical data show the same tendency for $\lambda_{\max }$. The change of the substituent on the tin atom of the stannole (Figure 1) leads only to a relatively small effect. $\lambda_{\max }$ is slightly bathochromically shifted by about $8 \mathrm{~nm}$ to $12 \mathrm{~nm}$. When the thiophene substituent in the 2- and 5-position (Figure 1) is 5-methoxy-thiophenyl instead of thiophenyl, $\lambda_{\max }$ is stronger bathochromically shifted by 
about $21 \mathrm{~nm}$ to $25 \mathrm{~nm}$. The experimentally measured molar extinction coefficients decreases for both 1-3 and 4-6 with the substituents $\mathrm{R}^{2}: \mathrm{A}>\mathrm{Ph}>\mathrm{PFB}$. All the optical characteristics are consistent with the information of the molecular orbital calculations (Table 1).
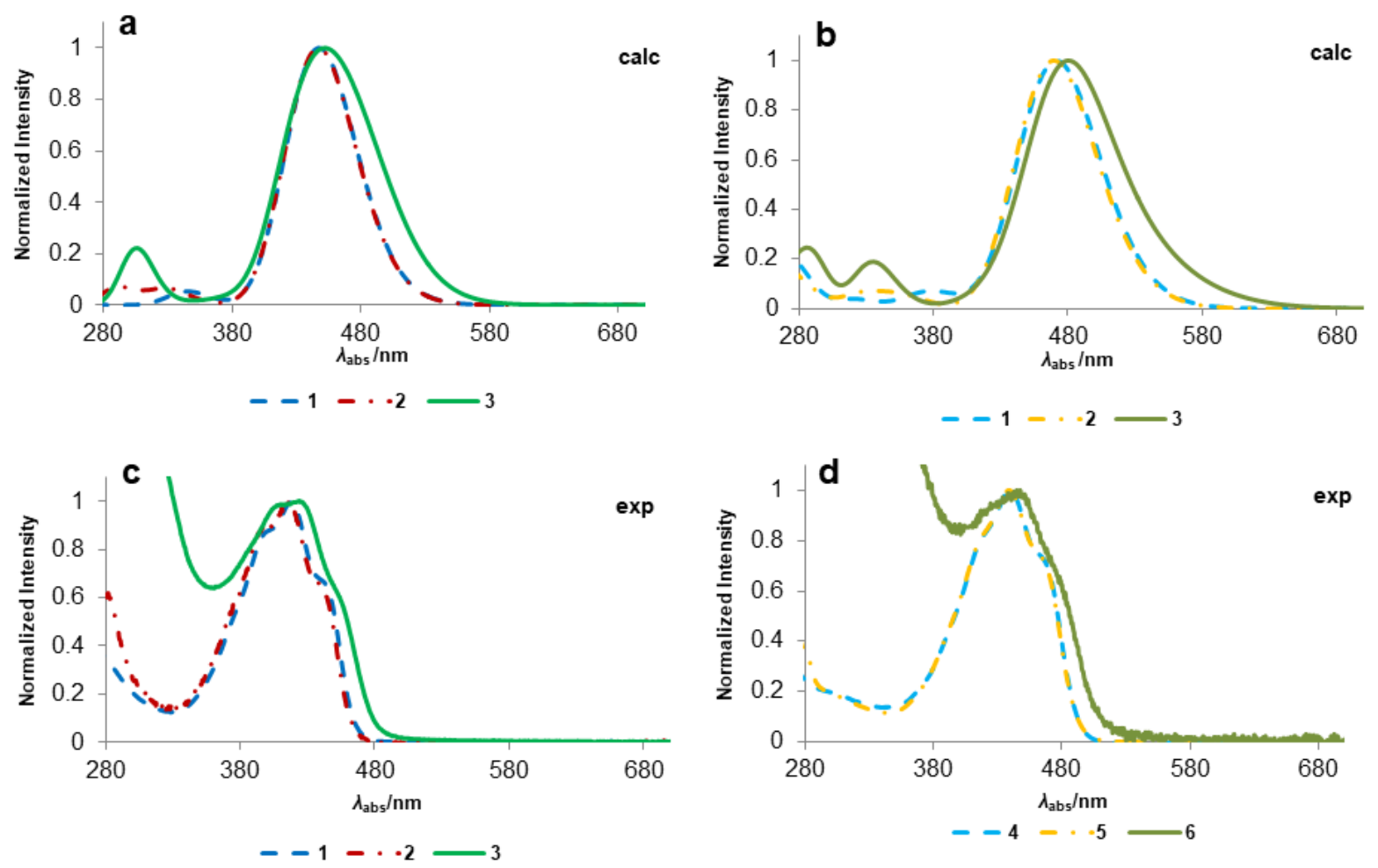

Figure 9. a) Calculated absorption spectra of stannoles 1-3; b) calculated absorption spectra of stannoles 4-6; c) experimental absorption spectra of stannoles 1-3; d) experimental absorption spectra of stannoles 4-6. All calculated spectra were arbitrarily broadened to approximately fit experimental resolution. 
Table 3. Theoretical and experimental absorption maxima (molar extinction coefficient).

\begin{tabular}{llll}
\hline Molecule & Theory & \multicolumn{2}{l}{ Experiment } \\
\hline & $\lambda_{\max } / \mathrm{nm}$ & $\lambda_{\max } / \mathrm{nm}$ & $\varepsilon /$ \\
& & & $\mathrm{L} \cdot \mathrm{mol}^{-1} \cdot \mathrm{cm}^{-1}$ \\
\hline $\mathbf{1}$ & 448 & 418 & 20146 \\
$\mathbf{2}$ & 447 & 415 & 13963 \\
$\mathbf{3}$ & 452 & 427 & 7296 \\
$\mathbf{4}$ & 472 & 440 & 28156 \\
$\mathbf{5}$ & 470 & 440 & 26590 \\
$\mathbf{6}$ & 481 & 448 & 7081 \\
$\mathbf{7}$ & 544 & $-^{\mathrm{a}}$ & $-^{\mathrm{a}}$ \\
$\mathbf{1 0}$ & 337 & $-^{\mathrm{a}}$ & $-^{\mathrm{a}}$ \\
\hline
\end{tabular}

a) These molecules were not prepared and only analyzed theoretically.

The absorption spectra for the peripherally nitro-thiophenyl substituted compound $\mathbf{7}$ and the peripherally pentafluorophenyl substituted stannole $\mathbf{1 0}$ were also calculated for comparative purposes, as their electronic structure (Figure 5) and the HOMO-LUMO gaps (Table 1) were significantly different from all other stannoles under investigation. Stannole 7 has a theoretical $\lambda_{\max }$ of $544 \mathrm{~nm}$, which is the strongest bathochromically shifted peak in the series; while $\mathbf{1 0}$ has a theoretical $\lambda_{\max }$ of $337 \mathrm{~nm}$, which is remarkably hypsochromically-shifted in comparison to the other stannoles. This confirms that the substituents in the 2- and 5-position have a much stronger influence on the electronic structure of the molecule than the substituents on the tin atom both on the HOMO-LUMO gap and the absorption maxima, certainly for large substituents. 


\section{Electrochemical Data}

The electrochemical behavior of the synthesized stannoles was studied by cyclic voltammetry (CV) measurements (Table 4, Figure 10).

Table 4. Electrochemical data for stannoles 1-3.

\begin{tabular}{lll}
\hline Molecule & $\boldsymbol{E}_{\mathbf{p a}} / \mathbf{V}$ & $\boldsymbol{E}_{\mathbf{p c}} / \mathbf{V}$ \\
& (versus ferrocene) & (versus ferrocene) \\
\hline $\mathbf{1}^{\mathrm{a}}$ & +0.37 & - \\
$\mathbf{2}^{\mathrm{b}}$ & +0.15 & - \\
$\mathbf{3}^{\mathrm{a}}$ & +1.02 & - \\
\hline
\end{tabular}

a) Scan rate was $0.1 \mathrm{~V} / \mathrm{s}$; b) Scan rate was $0.2 \mathrm{~V} / \mathrm{s}$.

The stannoles with unsubstituted thienyl substituents in the periphery display one irreversible oxidation step with no corresponding reduction step (see $\mathbf{1}, \mathbf{2}$ and $\mathbf{3}$ ). It appears that the unsubstituted thienyl groups are reactive under CV conditions.

Table 5. Electrochemical data for stannoles 4-6.

\begin{tabular}{|c|c|c|c|c|c|c|}
\hline Molecule $^{\mathrm{a}}$ & $\begin{array}{l}E_{\mathrm{p} 1 / 2} / \mathrm{V} \\
(\operatorname{versus} \mathrm{Fc})\end{array}$ & $\begin{array}{l}\mathbf{E} \text { ox onset } \\
/ \mathbf{V}\end{array}$ & $\begin{array}{l}\text { Calculated } \\
\text { HOMO } \\
(\mathrm{CV})^{\mathrm{a}} / \mathrm{eV}\end{array}$ & $\begin{array}{l}\text { Calculated } \\
\text { HOMO } \\
\text { (DFT)/eV }\end{array}$ & 1.IE/eV & 2.IE/eV \\
\hline 4 & $\begin{array}{l}-0.22 \\
-0.02\end{array}$ & -0.35 & -4.05 & -4.58 & 5.55 & 8.79 \\
\hline 5 & $\begin{array}{l}-0.15 \\
+0.07\end{array}$ & -0.30 & -4.10 & -4.52 & 5.47 & 8.66 \\
\hline 6 & $\begin{array}{l}-0.09 \\
-0.09\end{array}$ & -0.30 & -4.10 & -5.05 & 6.02 & 9.21 \\
\hline
\end{tabular}

a) All scan rates were $0.1 \mathrm{~V} / \mathrm{s}$.The HOMO energy was calculated using the $\mathrm{E}_{\text {onset }}$ for the first oxidation with the equation: $\mathrm{LUMO}=-\left(4.4+\mathrm{E}_{\text {onset }} \mathrm{Ox}\right) \mathrm{eV} .{ }^{60}$ 
The oxidation processes for compounds $\mathbf{4 , 5}$ and $\mathbf{6}$ on the other hand are reversible; in this case, the flanking thienyl groups all bear a methoxy group. This suggests that in the case of $\mathbf{1 - 3}$, this position might be involved in oxidation reactions. Stannoles $\mathbf{4}$ and $\mathbf{5}$ exhibit two reversible oxidation processes. At first glance, compound $\mathbf{6}$ only seemed to show one reversible oxidation process (Table 5). However, looking at the data very closely, a shoulder could be seen in the oxidation and reduction peaks. This suggests that both oxidation events are almost independent of one another in compound 6, whereas in compounds $\mathbf{4}$ and $\mathbf{5}$, the electrons are removed from the same delocalized system, making the second removal energetically less favorable, hence leading to a larger gap between the two oxidation events. For stannoles $\mathbf{4 , 5}$ and $\mathbf{6}$ also the adiabatic ionization energies were calculated (Table 5). From the DFT calculations, compound $\mathbf{5}$ should be first oxidized, then compound 4 and at the highest oxidation potential stannole $\mathbf{6}$ (Table 5 , column 5). However, the CV measurements show the order of an oxidation of $\mathbf{4}$ before 5 and $\mathbf{6}$ with rising potential for the first oxidation. The differences however are very small and may result from interactions of the molecule with the solvent and the electrodes. We could also observe experimentally that the electrodes were quickly contaminated by the substances.

The electrochemical behavior of stannole $\mathbf{4}$ and $\mathbf{5}$ is very similar which is in accordance with the findings from the calculations and the absorption spectra. Whether the substituent on the tin is phenyl or the much electron-richer anisole-motif, only leads to a small shift in the first oxidation wave $(\Delta \mathrm{Ep}=0.077 \mathrm{~V})$ between 4 and 5 and the second oxidation wave $(\Delta \mathrm{Ep}=0.09 \mathrm{~V})$ between 4 and 5. The calculations of the SOMOs (Singly Occupied Molecular Orbitals, see SI) of the monooxidized species showed qualitatively very similar electronic structures and offered no further explanations of why the cyclovoltammogram of $\mathbf{6}$ looked somewhat different from those of $\mathbf{4}$ and 5. 


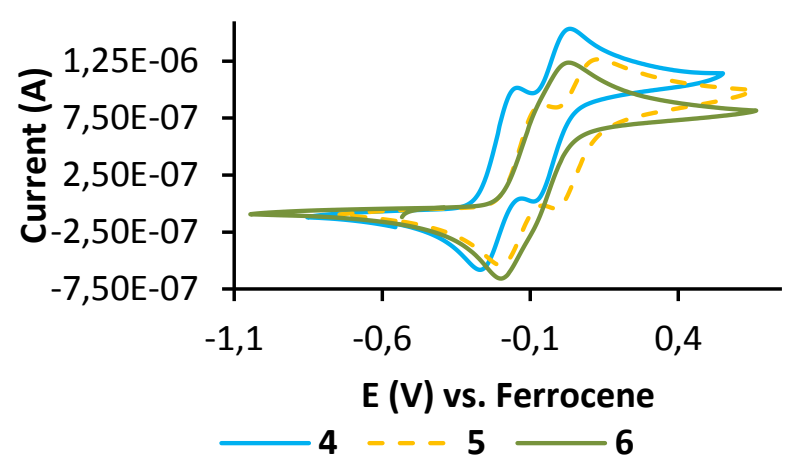

Figure 10. Reversible redox-processes of stannoles $4(5.2 \mathrm{mg} / \mathrm{mL}), 5(5.5 \mathrm{mg} / \mathrm{mL})$ and $\mathbf{6}$ (5.6 mg/mL), conducting salt: $0.1 \mathrm{M} \mathrm{Bu}_{4} \mathrm{NPF}_{6}$ in dichloromethane.

\section{CONCLUSIONS}

Calculations of geometries, energy gaps between HOMO and LUMO and absorption spectra of a wide range of stannoles were performed to understand the factors that govern the opto-electronic properties of these materials. Out of those, the most interesting compounds were selected for synthesis: a series of stannoles with different substituents in the periphery and on the tin atom. The influence of these substituents on the optical properties and electrochemical behavior was studied experimentally. Crystal structures of individual products were measured and torsion angles were compared to those obtained for the optimized geometries. These proved that the extended $\pi$-system comprised of the stannole and flanked by different thienyl groups is planar. This $\pi$-system has a larger influence on HOMO-LUMO gaps than the substituents on the tin atom; however it is clear that the absolute energy of the HOMO and LUMO levels is substantially influenced by the substituents on the tin even though the influence on the overall band gap is somewhat smaller. Therefore, the absorption maxima are only little affected; however the stability towards oxidation processes can be increased by introducing electron withdrawing groups on the tin atom. Because of the dominance of the conjugated $\pi$-system, any peripheral $\pi$-aromatic group whose plain is tilted 
against the dienyl-system of the stannole has a reduced effect. Therefore, five-membered heterocycles are preferable compared to six membered heterocycles.

Because of their small HOMO-LUMO gaps and the broad long-wavelength absorption spectra, stannoles with substituted thiophenes in the periphery or electron-withdrawing groups on the tin atom are promising building blocks in polymers for electronical devices like solar cells, provided they show reversible redox-processes. From the cyclic voltammetry studies we can assume that the molecules may have to be protected in the periphery of the thiophenes if electropolymerization processes are not desired. We are currently conducting research in our laboratories to elucidate the potential of stannoles for electropolymerization.

\section{EXPERIMENTAL SECTION}

Computational Details. The calculations were performed with the Gaussian 09 package. ${ }^{61}$ The optimized geometries of the stannoles (Figure 2) for the ground state, the adiabatic ionization energies and the SOMOs were calculated on B3LYP/LanL2DZ level of theory. ${ }^{62-65}$ This level of theory has been used for organotin compounds as reported in literature because the LanL2DZ basis includes both definitions for heavy metals like Sn (effective core potential and double zeta (DZ) quality valence basis set) as well as for light elements (all-electron basis set D95V for H-Ne). ${ }^{66}$ Frequency analyses were performed in all cases to confirm the absence of imaginary frequencies and thus prove that the obtained geometries corresponded to minimum on the potential energy surface. The Cartesian coordinates of each geometry and the respective energies are listed as part of the supporting information (SI). The absorption spectra were calculated based on the electronic structure information using time-dependent density functional theory (TD-DFT) with the B3LYP functional and LanL2DZ as basis set. ${ }^{61-65}$ Both singlet and triplet states were considered. NICS 
calculations (CSGT-B3LYP/LanL2DZ) ${ }^{62-65}$ were performed, whereby the NICS values were determined $1 \AA$ above the geometric center of the respective ring. ${ }^{67-69}$

\section{Materials and Methods.}

All reactions were carried out using standard Schlenk techniques under a dry, inert nitrogen atmosphere or inside a nitrogen filled glovebox from Inert, Innovative Technology, Inc. Company $\left(<0.1\right.$ ppm $\mathrm{O}_{2}$ and $\left.<0.1 \mathrm{ppm} \mathrm{H}_{2} \mathrm{O}\right)$ unless noted otherwise. All dry solvents were taken from the solvent purification system (SPS), degassed by three freeze-pump-thaw cycles and stored under a nitrogen atmosphere unless noted otherwise. Copper and palladium catalysts were stored in the glove box. All chemicals were commercially available and were used without further purification unless noted otherwise.

${ }^{1} \mathrm{H}$ NMR, ${ }^{13} \mathrm{C}$ NMR, ${ }^{19} \mathrm{~F}$ NMR and ${ }^{119}$ Sn NMR spectra were recorded on a Bruker DRX 500 at $300 \mathrm{~K}$. All ${ }^{1} \mathrm{H}$ NMR and ${ }^{13} \mathrm{C}$ NMR were referenced against the solvent residual proton signals $\left({ }^{1} \mathrm{H}\right)$, or the solvent itself $\left({ }^{13} \mathrm{C}\right) .{ }^{119} \mathrm{Sn}$ NMR spectra were calculated based on the ${ }^{1} \mathrm{H}$ NMR spectrum of tetramethylsilane. ${ }^{19} \mathrm{~F}$ NMR spectra were referenced against $\mathrm{BF}_{3} \cdot \mathrm{Et}_{2} \mathrm{O}$. All chemical $\delta$ shifts are given in parts per million (ppm) and all coupling constants $J$ in $\mathrm{Hz}$.

Column chromatography was carried out by using the column machine PuriFlash 4250 from Interchim. Silica gel columns of the type PF (PuriFlash) -15 ( $\mu \mathrm{m}$ grain size) SiHP (Silica gel High Performance) -F0012 (gram), PF-15SiHP-F0025, PF-50SiHP-JP-F0080, PF-50SiHP-JP-F0120, and PF-50SiHP-JP-F0220 were used. The sample was applied using a dry load method. The column material of the dry load was Celite 503 from Macherey-Nagel.

Cyclic voltammetry measurements were carried out with the potentiostat Autolab PGSTAT101 Metrohm. The material of the working electrode and the counter electrode was platinum. The material of the reference electrode was silver; all spectra were referenced against ferrocene. The 
scan rate was $0.1 \mathrm{~V} / \mathrm{s}$ for stannoles $\mathbf{1}, \mathbf{3}, \mathbf{4}, \mathbf{5}, \mathbf{6}$ and $0.2 \mathrm{~V} / \mathrm{s}$ for stannole 2 . The solvent was dichloromethane and the conducting salt was tetrabutylammonium hexafluorophosphate $\left(\mathrm{TBA}\left[\mathrm{PF}_{6}\right] 0.1 \mathrm{M}\right)$.

High resolution (HR) mass spectra were recorded on the double focusing mass spectrometer MAT 95+ from Finnigan Mat. Precision weights were determined via the peak-matching method. The reference substance was perfluorokerosene (PFK). The resolution (R) of the peak-matching performance was 10000 or 12000 . IR spectra were recorded on a Nicolet Thermo iS10 Scientific IR spectrometer with a diamond-ATR-unit. The resolution was $4 \mathrm{~cm}^{-1}$. Relative intensities of the IR bands were described by $\mathrm{s}=$ strong, $\mathrm{m}=$ medium or $\mathrm{w}=$ weak. UV/Vis spectra were recorded with a resolution of $0.1 \mathrm{~nm}$ on a UV-2700 spectrometer from Shimadzu with a double monochromator. The solvent was chloroform. All melting points were measured with a melting point apparatus by the company Gallenkamp and are uncorrected.

Crystallography. Intensity data of $\mathbf{1 , 4 , 5}$ and $\mathbf{3 7}$ were collected on a Bruker Venture D8 diffractometers at $100 \mathrm{~K}$ with graphite-monochromated Mo-K $\alpha(0.7107 \AA)$ radiation. All structures were solved by direct methods and refined based on F2 by use of the SHELX program package as implemented in WinGX. ${ }^{70-71}$ All non-hydrogen atoms were refined using anisotropic displacement parameters. Hydrogen atoms attached to carbon atoms were included in geometrically calculated positions using a riding model. Crystal and refinement data are collected in Table S1 (see SI). Figures were created using DIAMOND. ${ }^{72}$ Compounds 1 and 37 comprise 3 and 2 crystallographically independent, yet similar conformers. Disorder was resolved for the atoms $\mathrm{S} 6 / \mathrm{S} 6^{\prime}$ and $\mathrm{C} 81 / \mathrm{C} 81^{\prime}$ of 37 and refined with split occupancies of 60:40. Crystallographic data (excluding structure factors) for the structural analyses have been deposited with the Cambridge Crystallographic Data Centre. Copies of this information may be obtained free of 
charge from The Director, CCDC, 12 Union Road, Cambridge CB2 1EZ, UK (Fax: +44-1223336033; e-mail: deposit@ccdc.cam.ac.uk or http://www.ccdc.cam.ac.uk).

Synthesis of Thiophenyl-Flanked Stannoles 1, 2, 3. General procedure for the synthesis of the thiophenyl-flanked stannoles: 1,8-Bis(thiophen-2-yl)octa-1,7-diyne $(150 \mathrm{mg}, 550 \mu \mathrm{mol})$ and Rosenthal's zirconocene $(259 \mathrm{mg}, 550 \mu \mathrm{mol})$ were dissolved in toluene $(8 \mathrm{~mL})$. The dark red solution was stirred for $18 \mathrm{~h}$ at $20^{\circ} \mathrm{C}$ under a nitrogen atmosphere. The diaryl dichlorostannanes and copper (I) chloride $(5.4 \mathrm{mg}, 60 \mu \mathrm{mol})$ in toluene $(2 \mathrm{~mL})$ were added to the dark solution. The reaction mixture was stirred at $20^{\circ} \mathrm{C}$ for further $6 \mathrm{~h}$. The reactions were quenched with water $(1 \mathrm{x}$ $50 \mathrm{~mL})$ and extracted with dichloromethane $(3 \times 50 \mathrm{~mL})$. The combined organic layers were dried over magnesium sulfate, filtered and concentrated in vacuo. The crude product was washed with diethyl ether $(3 \times 5 \mathrm{~mL}$ ) and was purified by column chromatography (silica gel $15 \mu \mathrm{m}$ grain size, $n$-hexane).

Stannole 1: diphenyltin dichloride (189 $\mathrm{mg}, 0.55 \mathrm{mmol})$ was used to give the product as a yellow solid (95 mg, 32\%); $\mathrm{R}_{f}=0.36$; M.p.: $156{ }^{\circ} \mathrm{C} ;{ }^{1} \mathrm{H}$ NMR $\left(500 \mathrm{MHz}, \mathrm{CDCl}_{3}\right)^{2}: \delta 7.63(\mathrm{~m}, 2 \mathrm{H}$, H-12, H- 12')* 7.37 (m, 3H, H-13, H-14, H-13'), 7.26 (m, 1H, H-9) ${ }^{3}, 6.95$ (m, 2H, H-7, 8), 2.91 (m, 2H, H-4), 1.82 (m, 2H, H-5) ppm; ${ }^{13} \mathrm{C}\left\{{ }^{1} \mathrm{H}\right\} \mathrm{NMR}\left(126 \mathrm{MHz}, \mathrm{CDCl}_{3}\right)^{4}: \delta 149.7(\mathrm{C}-3) *, 145.9$ $(\mathrm{C}-11)^{*}, 138.2(\mathrm{C}-6), 137.4\left(\mathrm{C}-12, \mathrm{C}-12^{\prime}\right)^{*}, 130.2(\mathrm{C}-9), 129.5(\mathrm{C}-2)^{*}, 129.3(\mathrm{C}-14)^{*}, 129.0(\mathrm{C}-$ 13, C-13')* 127.1 (C-8), 125.9 (C-7), 31.9 (C-4), 23.4 (C-5) ppm; ${ }^{119} \mathrm{Sn}\left\{{ }^{1} \mathrm{H}\right\} \mathrm{NMR}(187 \mathrm{MHz}$, $\mathrm{CDCl}_{3}$ ): $\delta$-82.4 ppm; IR (ATR): $v=3060(\mathrm{w}), 2935(\mathrm{w}), 2359(\mathrm{w}), 1633(\mathrm{w}), 1515(\mathrm{w}), 1493(\mathrm{w})$ $1478(\mathrm{~m}), 1428(\mathrm{~m}), 1411(\mathrm{w}), 1381(\mathrm{w}), 1348(\mathrm{w}), 1329(\mathrm{w}), 1283(\mathrm{w}), 1250(\mathrm{w}), 1211(\mathrm{~m}), 1189$

\footnotetext{
${ }^{2}$ Signals that show satellites due to coupling with tin are marked with *.

${ }^{3}$ The integral of that peak is not exact, because the signal is overlapping with the peak of $\mathrm{CDCl}_{3}$.

${ }^{4}$ Signals that show satellites due to coupling with tin are marked with *.
} 
(w), $1134(\mathrm{w}), 1074(\mathrm{~m}), 1059(\mathrm{~m}), 1020(\mathrm{w}), 996(\mathrm{w}), 966(\mathrm{w}), 924(\mathrm{w}), 848(\mathrm{~m}), 801(\mathrm{~m}), 781$

(w), $723(\mathrm{~m}), 686(\mathrm{~s}) \mathrm{cm}^{-1}$. HR-MS (EI, $\left.\mathrm{C}_{28} \mathrm{H}_{24} \mathrm{~S}_{2}{ }^{116} \mathrm{Sn}\right)$ calcd 540.03314, found 540.03303 $(\mathrm{R}=$ 10000); MS (EI, $70 \mathrm{eV}$, direct inlet, $\left.200{ }^{\circ} \mathrm{C}\right): m / z(\%$ relative intensity $)=544(63)[\mathrm{M}]^{+}, 270(100)$ $\left[\mathrm{M}-\left(\mathrm{C}_{6} \mathrm{H}_{5}\right)_{2} \mathrm{Sn}\right]^{+} ; \lambda_{\max }\left(\right.$ chloroform, $\left.\varepsilon=2014.6 \mathrm{~cm}^{2} / \mathrm{mmol}\right)=418 \mathrm{~nm}$.

Stannole 2: di-(p-methoxyphenyl)dichlorostannane (222 mg, $550 \mu \mathrm{mol})$ was used to give the product as a yellow oil $(109 \mathrm{mg}, 33 \%) ; \mathrm{R}_{f}=0.16 ;{ }^{1} \mathrm{H} \mathrm{NMR}\left(500 \mathrm{MHz}, \mathrm{CDCl}_{3}\right)^{5}: \delta 7.53(\mathrm{~m}$, 2H, H-12, H-12' ')* 7.24 (m, 1H, H-9) ${ }^{6}, 6.94$ (m, 4H, H-13, H-13', H-7, H-8)* 3.79 (s, 3H, H15), 2.92 (m, 2H, H-4), 1.83 (m, 2H, H-5) ppm; ${ }^{13} \mathrm{C}\left\{{ }^{1} \mathrm{H}\right\} \mathrm{NMR}\left(126 \mathrm{MHz}, \mathrm{CDCl}_{3}\right)^{7}: \delta 160.8(\mathrm{C}-$ 14)*, $149.5(\mathrm{C}-3)^{*}, 146.0(\mathrm{C}-6)^{*}, 138.5\left(\mathrm{C}-12, \mathrm{C}-12^{\prime}\right)^{*}, 130.4(\mathrm{C}-11), 129.2$ (C-2)*, 128.5 (C-9), 127.0 (C-8), 125.8 (C-7), 114.9 (C-13, C-13')*, 55.1 (C-15), 31.9 (C-4), 23.4 (C-5) ppm; ${ }^{119} \mathrm{Sn}\left\{{ }^{1} \mathrm{H}\right\} \mathrm{NMR}\left(187 \mathrm{MHz}, \mathrm{CDCl}_{3}\right): \delta-74.8 \mathrm{ppm}$; IR (ATR): $v=2925(\mathrm{w}), 2858(\mathrm{w}), 2832(\mathrm{w})$, $1584(\mathrm{~m}), 1563$ (m), 1492 (m), 1455 (m), $1438(\mathrm{w}), 1411(\mathrm{w}), 1394(\mathrm{w}), 1347(\mathrm{w}), 1309(\mathrm{w}), 1278$ (m), 1242 (m), $1211(\mathrm{~m}), 1176(\mathrm{~m}), 1090$ (w), 1072 (m), 1025 (m), $924(\mathrm{w}), 901(\mathrm{w}), 851(\mathrm{~m}), 807$ (m), $787(\mathrm{~m}), 787(\mathrm{~m}), 687(\mathrm{~m}) \mathrm{cm}^{-1}$. HR-MS (EI, $\mathrm{C}_{30} \mathrm{H}_{28} \mathrm{O}_{2} \mathrm{~S}_{2}{ }^{116} \mathrm{Sn}$ ) calcd 600.05426, found $600.05475(\mathrm{R}=10000) ; \mathrm{MS}\left(\mathrm{EI}, 70 \mathrm{eV}\right.$, direct inlet, $\left.200^{\circ} \mathrm{C}\right): \mathrm{m} / z(\%$ relative intensity $)=604(74)$ $[\mathrm{M}]^{+}, 270(100)\left[\mathrm{M}-\left(\mathrm{C}_{7} \mathrm{H}_{7} \mathrm{O}\right)_{2} \mathrm{Sn}\right]^{+} ; \lambda_{\max }\left(\right.$ chloroform, $\left.\varepsilon=1396.3 \mathrm{~cm}^{2} / \mathrm{mmol}\right)=415 \mathrm{~nm}$.

Stannole 3: di-(pentafluorophenyl)dichlorostannane $(282 \mathrm{mg}, 550 \mu \mathrm{mol})$ was used to give the product as an orange-yellow oil $(23 \mathrm{mg}, 6 \%) ; \mathrm{R}_{f}=0.13 ;{ }^{1} \mathrm{H}$ NMR $\left(500 \mathrm{MHz}, \mathrm{CDCl}_{3}\right): 7.21\left(\mathrm{~d},{ }^{3} \mathrm{~J}\right.$ $=5.1 \mathrm{~Hz}, 1 \mathrm{H}, \mathrm{H}-9), 6.88\left(\mathrm{dd},{ }^{3} J=5.1 \mathrm{~Hz},{ }^{3} J=3.7 \mathrm{~Hz}, 1 \mathrm{H}, \mathrm{H}-7\right), 6.82\left(\mathrm{~d},{ }^{3} J=3.7 \mathrm{~Hz}, 1 \mathrm{H} \mathrm{H}-8\right)$,

\footnotetext{
${ }^{5}$ Signals that show satellites due to coupling with tin are marked with *.

${ }^{6}$ The integral of that peak is not exact, because the signal is overlapping with the peak of $\mathrm{CDCl}_{3}$.

${ }^{7}$ Signals that show satellites due to coupling with tin are marked with *.
} 
$2.94(\mathrm{~m}, 2 \mathrm{H}, \mathrm{H}-4), 1.86$ (m, 2H, H-5) ppm; ${ }^{13} \mathrm{C}\left\{{ }^{1} \mathrm{H}\right\} \mathrm{NMR}^{8}\left(126 \mathrm{MHz}, \mathrm{CDCl}_{3}\right)^{9}: \delta 148.5(\mathrm{C}-3) *$ 144.8 (C-6), 129.7 (C-2)*, 128.9 (C-9), 127.0 (C-8), 125.9 (C-7), 31.5 (C-4), 23.1 (C-5) ppm; ${ }^{119} \mathrm{Sn}\left\{{ }^{1} \mathrm{H}\right\} \mathrm{NMR}\left(187 \mathrm{MHz}, \mathrm{CDCl}_{3}\right): \delta-152.7 \mathrm{ppm} ;{ }^{19} \mathrm{~F} \mathrm{NMR}\left(188 \mathrm{MHz}, \mathrm{CDCl}_{3}\right):-158.2\left(\mathrm{dd},{ }^{3} \mathrm{~J}=\right.$ $\left.19.3 \mathrm{~Hz},{ }^{3} J=16.7 \mathrm{~Hz}, 2 \mathrm{~F}, \mathrm{~F}-13, \mathrm{~F}-13^{\prime \prime}\right),-147.0\left(\mathrm{t},{ }^{3} \mathrm{~J}=19.3 \mathrm{~Hz}, 1 \mathrm{~F}, \mathrm{~F}-14\right),-122.3\left(\mathrm{~d},{ }^{3} J=16.7 \mathrm{~Hz}\right.$, 2F, F-12, F-12') ppm; IR (ATR): $v=3889$ (w), 3850 (w), 3742 (w), 3695 (w), 2442 (w), 2325 (w), $2226(w), 2164$ (w), 2124 (w), 1997 (w), 1951 (w), 975 (w) cm"-1 HR-MS (EI, $\mathrm{C}_{28} \mathrm{H}_{14} \mathrm{~F}_{10} \mathrm{~S}_{2}{ }^{116} \mathrm{Sn}$ ) calcd 719.93892, found $719.93844(\mathrm{R}=10000)$; MS (EI, $70 \mathrm{eV}$, direct inlet, $\left.200{ }^{\circ} \mathrm{C}\right): m / z(\%$ relative intensity $)=724(30)[\mathrm{M}]^{+}, 270(100)\left[\mathrm{M}-\left(\mathrm{C}_{6} \mathrm{~F}_{5}\right){ }_{2} \mathrm{Sn}\right]^{+}$;

$\lambda_{\max }\left(\right.$ chloroform, $\left.\varepsilon=729.6 \mathrm{~cm}^{2} / \mathrm{mmol}\right)=427 \mathrm{~nm}$.

Synthesis of Methoxy-Thiophenyl-Flanked Stannoles 4, 5 and 6. General procedure for the synthesis of the methoxy-thiophenyl-flanked stannoles: 1,8-Bis(5-methoxy-thiophen-2-yl)octa1,7-diyne (150 mg, $450 \mu \mathrm{mol})$ and Rosenthal's zirconocene $(211 \mathrm{mg}, 450 \mu \mathrm{mol})$ were dissolved in toluene $(8 \mathrm{~mL})$. The dark red solution was stirred for $18 \mathrm{~h}$ at $20^{\circ} \mathrm{C}$ under a nitrogen atmosphere. The diaryl dichlorostannanes and copper (I) chloride $(5.0 \mathrm{mg}, 50 \mu \mathrm{mol})$ in toluene $(2 \mathrm{~mL})$ were added to the dark solution. The reaction mixture was stirred at $20^{\circ} \mathrm{C}$ for further $6 \mathrm{~h}$. The reactions were quenched with water $(1 \times 50 \mathrm{~mL})$ and extracted with dichloromethane $(3 \times 50 \mathrm{~mL})$. The combined organic layers were dried over magnesium sulfate, filtered and concentrated in vacuo. The crude product was washed with diethyl ether $(3 \times 5 \mathrm{~mL})$ and was purified by column chromatography (silica gel $15 \mu \mathrm{m}$ grain size, $n$-hexane).

\footnotetext{
${ }^{8}{ }^{13} \mathrm{C}\left\{{ }^{19} \mathrm{~F}\right\}$ NMR was not possible to measure; therefore the signal intensity was too low for identification of the carbon atoms attached with fluorine.

${ }^{9}$ Signals that show satellites due to coupling with tin are marked with *.
} 
Stannole 4: diphenyltin dichloride $(155 \mathrm{mg}, 450 \mu \mathrm{mol})$ was used to give the product as an orange-yellow solid (96 mg, 35\%); $\mathrm{R}_{f}=0.30$; M.p.: $178{ }^{\circ} \mathrm{C} ;{ }^{1} \mathrm{H}$ NMR $\left(500 \mathrm{MHz}, \mathrm{CDCl}^{3}\right)^{10}: \delta 7.63$ (m, 2H, H-13, H-13')*, 7.37 (m, 3H, H-14, H-15, H-14'), 6.59 (d, ${ }^{3} J=4.0$ Hz, 1H, H-7), 6.07 (d, $\left.{ }^{3} J=4.0 \mathrm{~Hz}, 1 \mathrm{H}, \mathrm{H}-8\right), 3.86(\mathrm{~s}, 3 \mathrm{H}, \mathrm{H}-11), 2.78(\mathrm{~m}, 2 \mathrm{H}, \mathrm{H}-4), 1.77$ (m, 2H, H-5) ppm; ${ }^{13} \mathrm{C}\left\{{ }^{1} \mathrm{H}\right\}$ NMR $\left(126 \mathrm{MHz}, \mathrm{CDCl}_{3}\right){ }^{11}: \delta 166.8(\mathrm{C}-9), 146.3(\mathrm{C}-3), 138.6(\mathrm{C}-12), 137.3(\mathrm{C}-13, \mathrm{C}-$ $\left.13^{\prime}\right)^{*}, 132.6(\mathrm{C}-6)^{*}, 130.1(\mathrm{C}-2)^{*}, 129.4(\mathrm{C}-15)^{*}, 128.9\left(\mathrm{C}-14, \mathrm{C}-14^{\prime}\right)^{*}, 127.0(\mathrm{C}-7), 104.1(\mathrm{C}-8)$, 60.0 (C-11), 31.6 (C-4), 23.5 (C-5) ppm; ${ }^{119} \mathrm{Sn}\left\{{ }^{1} \mathrm{H}\right\} \mathrm{NMR}\left(187 \mathrm{MHz}, \mathrm{CDCl}_{3}\right): \delta$-78.3 ppm; IR (ATR): $v=3742(\mathrm{w}), 2439(\mathrm{w}), 2323(\mathrm{w}), 2220(\mathrm{w}), 2118(\mathrm{w}), 1985(\mathrm{w}), 1952(\mathrm{w}), 1245(\mathrm{w})$, $1177(w), 1076(w), 994(w), 978(w), 949(w), 806(w), 790(w), 762(w), 692(w), 673(\mathrm{~m}) \mathrm{cm}^{-}$ 1. HR-MS (EI, $\mathrm{C}_{30} \mathrm{H}_{28} \mathrm{O}_{2} \mathrm{~S}_{2}{ }^{116} \mathrm{Sn}$ ) calcd 600.05426, found 600.05402 (R = 10000); MS (EI, $70 \mathrm{eV}$, direct inlet, $\left.200{ }^{\circ} \mathrm{C}\right): m / z(\%$ relative intensity $)=604(40)[\mathrm{M}]^{+}, 315(100)\left[\mathrm{M}-\left(\mathrm{C}_{6} \mathrm{H}_{5}\right)_{2} \mathrm{Sn}_{-} \mathrm{CH}_{3}\right]^{+}$; $\lambda_{\max }\left(\right.$ chloroform, $\left.\varepsilon=2815.6 \mathrm{~cm}^{2} / \mathrm{mmol}\right)=440 \mathrm{~nm}$.

Stannole 5: di-(p-methoxyphenyl)dichlorostannane (182 mg, $450 \mu \mathrm{mol})$ was used to give the product as an orange solid $(89 \mathrm{mg}, 30 \%) ; \mathrm{R}_{f}=0.21$; M.p.: $160{ }^{\circ} \mathrm{C} ;{ }^{1} \mathrm{H} \mathrm{NMR}\left(500 \mathrm{MHz}, \mathrm{CDCl}_{3}\right)^{12}$ : $\delta 7.53\left(\mathrm{~d},{ }^{3} J=8.6 \mathrm{~Hz}, 2 \mathrm{H}, \mathrm{H}-13, \mathrm{H}-13^{\prime}\right)^{*}, 6.93\left(\mathrm{~d},{ }^{3} J=8.6 \mathrm{~Hz}, 2 \mathrm{H}, \mathrm{H}-14, \mathrm{H}-14^{\prime}\right), 6.57\left(\mathrm{~d},{ }^{3} J=\right.$ $4.0 \mathrm{~Hz}, 1 \mathrm{H}, \mathrm{H}-7), 6.06$ (d, $\left.{ }^{3} \mathrm{~J}=4.0 \mathrm{~Hz}, 1 \mathrm{H}, \mathrm{H}-8\right), 3.86$ (s, 3H, H-11), 3.79 (s, 3H, H-16), 2.80 (m, 2H, H-4), 1.77 (m, 2H, H-5) ppm; ${ }^{13} \mathrm{C}\left\{{ }^{1} \mathrm{H}\right\} \mathrm{NMR}\left(126 \mathrm{MHz}, \mathrm{CDCl}_{3}\right){ }^{13}: \delta 166.7$ (C-9), 160.77 (C15), 146.1 (C-3), 138.5 (C-13, C-13')*, $132.8(\mathrm{C}-12)^{*}, 130.3(\mathrm{C}-6)^{*}, 129.0(\mathrm{C}-2)^{*}, 126.9$ (C-7), $114.8\left(\mathrm{C}-14, \mathrm{C}-14^{\prime}\right)^{*}, 104.1$ (C-8), 60.0 (C-11), 55.1 (C-16), 31.6 (C-4), 23.5 (C-5) ppm; ${ }^{119} \mathrm{Sn}\left\{{ }^{1} \mathrm{H}\right\} \mathrm{NMR}\left(187 \mathrm{MHz}, \mathrm{CDCl}_{3}\right): \delta-71.2 \mathrm{ppm}$; IR (ATR): $v=3878(\mathrm{w}), 3851(\mathrm{w}), 3748(\mathrm{w})$,

\footnotetext{
${ }^{10}$ Signals that show satellites due to coupling with tin are marked with *.

${ }^{11}$ Signals that show satellites due to coupling with tin are marked with *.

12 Signals that show satellites due to coupling with tin are marked with *.

${ }^{13}$ Signals that show satellites due to coupling with tin are marked with *.
} 
$2584(w), 2543(w), 2472(w), 2440(w), 2323(w), 2224(w), 2120(w), 1989(w), 1947(w), 1877$ (w), $1843(\mathrm{w}), 1757(\mathrm{w}), 1251(\mathrm{w}), 1161(\mathrm{w}), 1123(\mathrm{w}), 1011(\mathrm{w}), 995(\mathrm{w}), 978(\mathrm{w}), 917(\mathrm{w}), 885$ (w), $774(\mathrm{w}), 765(\mathrm{w}) \mathrm{cm}^{-1}$. HR-MS (EI, $\left.\mathrm{C}_{32} \mathrm{H}_{32} \mathrm{O}_{4} \mathrm{~S}_{2}{ }^{116} \mathrm{Sn}\right)$ calcd 660.07539, found $660.07426(\mathrm{R}$ $=10000) ; \mathrm{MS}\left(\mathrm{EI}, 70 \mathrm{eV}\right.$, direct inlet, $\left.200{ }^{\circ} \mathrm{C}\right): \mathrm{m} / \mathrm{z}(\%$ relative intensity $)=664(36)[\mathrm{M}]^{+}, 315$ (100) $\left[\mathrm{M}-\left(\mathrm{C}_{7} \mathrm{H}_{7} \mathrm{O}\right)_{2} \mathrm{Sn}-\mathrm{CH}_{3}\right]^{+} ; \lambda_{\max }\left(\right.$ chloroform, $\left.\varepsilon=2659.0 \mathrm{~cm}^{2} / \mathrm{mmol}\right)=440 \mathrm{~nm}$.

Stannole 6: di-(pentafluorophenyl)dichlorostannane $(236 \mathrm{mg}, 450 \mathrm{mmol})$ was used to give the product as an orange oil $(27 \mathrm{mg}, 8 \%) ; \mathrm{R}_{f}=0.10 ;{ }^{1} \mathrm{H} \mathrm{NMR}\left(500 \mathrm{MHz}, \mathrm{CDCl}_{3}\right): 6.56\left(\mathrm{~d},{ }^{3} \mathrm{~J}=4.0 \mathrm{~Hz}\right.$, 1H, H-7), 6.11 (d, $\left.{ }^{3} J=4.0 \mathrm{~Hz},{ }^{3} J=4.0 \mathrm{~Hz}, 1 \mathrm{H}, \mathrm{H}-8\right), 3.88$ (s, 3H, H-11), 2.81 (m, 2H, H-4), 1.77 (m, 2H, H-5) ppm; ${ }^{13} \mathrm{C}\left\{{ }^{1} \mathrm{H}\right\} \mathrm{NMR}^{14}\left(126 \mathrm{MHz}, \mathrm{CDCl}_{3}\right): \delta 167.5$ (C-9), 145.5 (C-3), 130.0 (C-6), 127.5 (C-7), 125.9 (C-2), 104.0 (C-8), 59.9 (C-10), 31.2 (C-4), 22.9 (C-5) ppm; ${ }^{119} \mathrm{Sn}\left\{{ }^{1} \mathrm{H}\right\} \mathrm{NMR}$ $\left(187 \mathrm{MHz}, \mathrm{CDCl}_{3}\right): \delta-145.1 \mathrm{ppm} ;{ }^{19} \mathrm{~F}$ NMR $\left(188 \mathrm{MHz}, \mathrm{CDCl}_{3}\right):-159.6\left(\mathrm{~m}, 2 \mathrm{~F}, \mathrm{~F}-14, \mathrm{~F}-14^{\prime}\right),-$ $150.0\left(\mathrm{t},{ }^{3} J=19.7 \mathrm{~Hz}, 1 \mathrm{~F}, \mathrm{~F}-15\right),-120.2\left(\mathrm{~d},{ }^{3} J=15.8 \mathrm{~Hz}, 2 \mathrm{~F}, \mathrm{~F}-13, \mathrm{~F}-13^{\prime}\right) \mathrm{ppm}$; IR (ATR): $v=$ $2928(w), 2825(w), 1716(w), 1626(w), 1469(w), 1416(m), 1313(w), 1274(w), 1230(w), 1200$ (m), 1149 (w), 1088 (w), 1039 (w), 989 (m), 875 (w), 765 (m), 713 (w), 694 (w), cm-1; HR-MS (EI, $\mathrm{C}_{30} \mathrm{H}_{18} \mathrm{~F}_{10} \mathrm{O}_{2} \mathrm{~S}_{2}{ }^{120} \mathrm{Sn}$ ) calcd 783.96050, found $783.96077(\mathrm{R}=10000)$; MS (EI, $70 \mathrm{eV}$, direct inlet, $\left.200{ }^{\circ} \mathrm{C}\right): \mathrm{m} / \mathrm{z}(\%$ relative intensity $)=784(95)[\mathrm{M}]^{+}, 315(100)\left[\mathrm{M}-\left(\mathrm{C}_{6} \mathrm{~F}_{5}\right)_{2} \mathrm{Sn}_{-}-\mathrm{CH}_{3}\right]^{+} ; \lambda_{\max }$ (chloroform, $\varepsilon=708.1 \mathrm{~cm}^{2} / \mathrm{mmol}$ ) $=448 \mathrm{~nm}$.

\footnotetext{
${ }^{14}{ }^{13} \mathrm{C}\left\{{ }^{19} \mathrm{~F}\right\}$ NMR was not possible to measure; therefore the signal intensity was too low for identification of the carbon atoms attached with fluorine.
} 


\section{ASSOCIATED CONTENT}

\section{Supporting Information}

The Supporting Information is available free of charge on the ACS Publications website. It includes experimental and analytical details, NMR spectra, cyclic voltammetry and absorption spectra (PDF), crystal structure information (CIF) and all computational data (TXT).

\section{AUTHOR INFORMATION}

\section{Corresponding Author}

* E-mail for A.S.: staubitz@uni-bremen.de.

ORCID

Anne Staubitz: orcid.org/0000-0002-9040-3297

Isabel-Maria Ramirez y Medina: orcid.org/0000-0003-2477-664X

Markus Rohdenburg: orcid.org/0000-0001-8533-3610

Farzin Mostaghimi: orcid.org/0000-0002-7840-7615

Jens Beckmann: orcid.org/0000-0002-8548-1821

Petra Swiderek: orcid.org/0000-0002-4355-5546

Simon Grabowsky: orcid.org/0000-0002-3377-9474

Jonas Hoffmann: orcid.org/0000-0003-4769-5631

Muriel Hissler: orcid.org/0000-0003-1992-1814 
Vincent Dorcet: orcid.org/0000-0001-9423-995X

\section{Author Contributions}

The manuscript was written through contributions of all authors. All authors have given approval to the final version of the manuscript.

\section{Funding Sources}

Emmy Noether scheme project GR 4451/1-1

COST action COST 1302

Notes

The authors declare no competing financial interest.

\section{ACKNOWLEDGMENT}

This research has been supported by the Institutional Strategy of the University of Bremen, funded by the German Excellence Initiative. We thank Mathias Gogolin for synthetic assistance with compound 23. We thank Dr. Thomas Dülcks and Dorit Kempken for measuring mass spectra and Prof. Dr. Frank Sönnichsen from Kiel University for measuring NMR samples. S. Grabowsky thanks the German Research Foundation (DFG) for funding within the Emmy-Noether scheme (project GR 4451/1-1). J. Hoffmann acknowledges funding for a Short Term Scientific Mission from the COST action COST 1302: 'European Network on Smart Inorganic Polymers' This work is supported by the Ministère de la Recherche et de l'Enseignement Supérieur, the CNRS, the Région Bretagne and COST CM 1302 (SIPS). 


\section{REFERENCES}

1. Saito, M., Challenge to expand the concept of aromaticity to tin- and lead-containing carbocyclic compounds: Synthesis, structures and reactions of dilithiostannoles and dilithioplumbole. Coord. Chem. Rev. 2012, 256, 627-636.

2. Lee, V. Y.; Sekiguchi, A., Aromaticity of Group 14 Organometallics: Experimental Aspects. Angew. Chem. Int. Ed. 2007, 46, 6596-6620.

3. Saito, M.; Haga, R.; Yoshioka, M.; Ishimura, K.; Nagase, S., The Aromaticity of the Stannole Dianion. Angew. Chem. Int. Ed. 2005, 44, 6553-6556.

4. Urrego- Riveros, S.; Ramirez y Medina, I. M.; Hoffmann, J.; Heitmann, A.; Staubitz, A., Syntheses and Properties of Tin- Containing Conjugated Heterocycles. Chem. Eur. J. 2018, 24, 5680-5696.

5. Mizuhata, Y.; Sasamori, T.; Takeda, N.; Tokitoh, N., A Stable Neutral Stannaaromatic Compound: Synthesis, Structure and Complexation of a Kinetically Stabilized 2-

Stannanaphthalene. J. Am. Chem. Soc. 2006, 128, 1050-1051.

6. Heinrich, A. C. J.; Thiedemann, B.; Gates, P. J.; Staubitz, A., Dual Selectivity:

Electrophile and Nucleophile Selective Cross-Coupling Reactions on a Single Aromatic Substrate. Org. Lett. 2013, 15, 4666-4669.

7. Linshoeft, J.; Heinrich, A. C. J.; Segler, S. A. W.; Gates, P. J.; Staubitz, A., Chemoselective Cross-Coupling Reactions with Differentiation between Two Nucleophilic Sites on a Single Aromatic Substrate. Org. Lett. 2012, 14, 5644-5647.

8. He, L.-Y.; Urrego-Riveros, S.; Gates, P. J.; Näther, C.; Brinkmann, M.; Abetz, V.; Staubitz, A., Synthesis of poly(thiophene-alt-pyrrole) from a difunctionalized thienylpyrrole by Kumada polycondensation. Tetrahedron 2015, 71, 5399-5406.

9. Wu, J.-S.; Cheng, S.-W.; Cheng, Y.-J.; Hsu, C.-S., Donor-acceptor conjugated polymers based on multifused ladder-type arenes for organic solar cells. Chem. Soc. Rev. 2015, 44, 11131154.

10. Bundgaard, E.; Krebs, F. C., Low band gap polymers for organic photovoltaics. Sol. Energy Mater. Sol. Cells 2007, 91, 954-985.

11. Ajayaghosh, A., Donor-acceptor type low band gap polymers: polysquaraines and related systems. Chem. Soc. Rev. 2003, 32, 181-191.

12. Perepichka, D. F.; Bryce, M. R., Molecules with Exceptionally Small HOMO-LUMO Gaps. Angew. Chem. Int. Ed. 2005, 44, 5370-5373.

13. Braunschweig, H.; Fernández, I.; Frenking, G.; Kupfer, T., Structural Evidence for Antiaromaticity in Free Boroles. Angew. Chem. Int. Ed. 2008, 47, 1951-1954.

14. Hay, C.; Hissler, M.; Fischmeister, C.; Rault-Berthelot, J.; Toupet, L.; Nyulászi, L.; Réau, R., Phosphole-Containing $\pi$-Conjugated Systems: From Model Molecules to Polymer Films on Electrodes. Chem. Eur. J. 2001, 7, 4222-4236.

15. Duffy, M. P.; Delaunay, W.; Bouit, P. A.; Hissler, M., [small pi]-Conjugated phospholes and their incorporation into devices: components with a great deal of potential. Chem. Soc. Rev. 2016, 45, 5296-5310.

16. Thiedemann, B.; Gliese, P. J.; Hoffmann, J.; Lawrence, P. G.; Sonnichsen, F. D.; Staubitz, A., High molecular weight poly ( $N$-methyl- $B$-vinylazaborine) - a semi-inorganic B-N polystyrene analogue. Chem. Commun. 2017, 53, 7258-7261. 
17. Baggett, A. W.; Guo, F.; Li, B.; Liu, S.-Y.; Jäkle, F., Regioregular Synthesis of Azaborine Oligomers and a Polymer with a syn Conformation Stabilized by $\mathrm{N}-\mathrm{H} \cdots \pi$ Interactions. Angew. Chem. Int. Ed. 2015, 54, 11191-11195.

18. Leavitt, F. C.; Manuel, T. A.; Johnson, F., Novel Heterocyclopentadienes. J. Am. Chem. Soc. 1959, 81, 3163-3164.

19. Ashe, A. J.; Drone, F. J., Synthesis of 2,2,',5,5'-tetramethylbibismole. A thermochromic dibismuthine. Organometallics 1984, 3, 495 - 496.

20. Katkevics, M.; Yamaguchi, S.; Toshimitsu, A.; Tamao, K., From Tellurophenes to Siloles. Synthesis, Structures, and Photophysical Properties of 3,4-Unsubstituted 2,5Diarylsiloles. Organometallics 1998, 17, 5796-5800.

21. Wrackmeyer, B.; Kundler, S.; Boese, R., Routes to Stannoles, Stannolenes and 1-Stanna4-bora-2,5-cyclohexadienes - Crystal Structure of a Triorganotin Cation Stabilized by $\pi 1$ Coordination. Chem. Ber. 1993, 126, 1361-1370.

22. Yamaguchi, S.; Itami, Y.; Tamao, K., Group 14 Metalloles with Thienyl Groups on 2,5Positions: Effects of Group 14 Elements on Their $\pi$-Electronic Structures. Organometallics 1998, 17, 4910-4916.

23. Deng, C.-M.; Niu, Y.-L.; Peng, Q.; Shuai, Z.-G., Electronic Structures and Spectroscopic Properties of Group-14 Metalloles $\mathrm{MPh}_{6}(\mathrm{M}=\mathrm{Si}, \mathrm{Ge}, \mathrm{Sn})$. Acta Phys. Chim. Sin. 2010, 26, 10511058 .

24. Jorner, K.; Emanuelsson, R.; Dahlstrand, C.; Tong, H.; Denisova, A. V.; Ottosson, H., Impact of Ground- and Excited-State Aromaticity on Cyclopentadiene and Silole Excitation Energies and Excited-State Polarities. Chem. Eur. J. 2014, 20, 9295-9303.

25. Chen, J.; Cao, Y., Silole-Containing Polymers: Chemistry and Optoelectronic Properties. Macromol. Rapid Commun. 2007, 28, 1714-1742.

26. Guo, X.; Zhou, N.; Lou, S. J.; Hennek, J. W.; Ponce Ortiz, R.; Butler, M. R.; Boudreault, P.-L. T.; Strzalka, J.; Morin, P.-O.; Leclerc, M.; López Navarrete, J. T.; Ratner, M. A.; Chen, L. X.; Chang, R. P. H.; Facchetti, A.; Marks, T. J., Bithiopheneimide-

Dithienosilole/Dithienogermole Copolymers for Efficient Solar Cells: Information from Structure-Property-Device Performance Correlations and Comparison to Thieno[3,4-c]pyrrole4,6-dione Analogues. J. Am. Chem. Soc. 2012, 134, 18427-18439.

27. Denisova, A.; Tibbelin, J.; Emanuelsson, R.; Ottosson, H., A Computational Investigation of the Substituent Effects on Geometric, Electronic, and Optical Properties of Siloles and 1,4-Disilacyclohexa-2,5-dienes. Molecules 2017, 22, 370.

28. Lucht, B. L.; Buretea, M. A.; Tilley, T. D., Poly(2,5-diphenylgermole): Incorporation of a Germole Ring into a Conjugated Polymer. Organometallics 2000, 19, 3469-3475.

29. Wrackmeyer, B.; Pedall, A.; Milius, W.; Ali, S.; Ponomarev, S. V., Novel Germoles and Stannoles With Unexpected Properties. Main Group Met. Chem. 2001, 24, 603-608.

30. Haga, R.; Saito, M.; Yoshioka, M., Synthesis and Reactions of Stannole Anions. Eur. J. Inorg. Chem. 2007, 2007, 1297-1306.

31. Saito, M.; Sakaguchi, M.; Tajima, T.; Ishimura, K.; Nagase, S.; Hada, M., Dilithioplumbole: A Lead-Bearing Aromatic Cyclopentadienyl Analog. Science 2010, 328, 339342 .

32. Wrackmeyer, B.; Horchler, K., Plumboles bearing organometallic substituents. Their synthesis and reaction mechanism, as studied by multinuclear magnetic resonance spectroscopy. J. Organomet. Chem. 1990, 399, 1-10. 
33. Hissler, M.; Dyer, P. W.; Réau, R., Linear organic $\pi$-conjugated systems featuring the heavy Group 14 and 15 elements. Coord. Chem. Rev. 2003, 244, 1-44.

34. Zhang, F.-B.; Adachi, Y.; Ooyama, Y.; Ohshita, J., Synthesis and Properties of Benzofuran-Fused Silole and Germole Derivatives: Reversible Dimerization and Crystal Structures of Monomers and Dimers. Organometallics 2016, 35, 2327-2332.

35. Murakami, K.; Ooyama, Y.; Higashimura, H.; Ohshita, J., Synthesis, Properties, and Polymerization of Spiro[(dipyridinogermole)(dithienogermole)]. Organometallics 2016, 35, 2026.

36. Ohshita, J.; Kai, H.; Takata, A.; Iida, T.; Kunai, A.; Ohta, N.; Komaguchi, K.; Shiotani, M.; Adachi, A.; Sakamaki, K.; Okita, K., Effects of Conjugated Substituents on the Optical, Electrochemical, and Electron-Transporting Properties of Dithienosiloles. Organometallics 2001, 20, 4800-4805.

37. van Beelen, D. C.; Wolters, J.; van der Gen, A., Some spectroscopic properties of cyclic organolead compounds I. J. Organomet. Chem. 1978, 145, 359-363.

38. Geramita, K.; McBee, J.; Tilley, T. D., 2,7-Substituted Hexafluoroheterofluorenes as Potential Building Blocks for Electron Transporting Materials. J. Org. Chem. 2009, 74, 820-829. 39. Nagao, I.; Shimizu, M.; Hiyama, T., 9-Stannafluorenes: 1,4-Dimetal Equivalents for Aromatic Annulation by Double Cross-Coupling. Angew. Chem. 2009, 121, 7709-7712.

40. Saito, M.; Tanikawa, T.; Tajima, T.; Guo, J. D.; Nagase, S., Synthesis and structures of heterasumanenes having different heteroatom functionalities. Tetrahedron Lett. 2010, 51, 672675 .

41. Zhao, Z.; He, B.; Tang, B. Z., Aggregation-induced emission of siloles. Chem. Sci. 2015, 6, 5347-5365.

42. Hou, J.; Chen, H.-Y.; Zhang, S.; Li, G.; Yang, Y., Synthesis, Characterization, and Photovoltaic Properties of a Low Band Gap Polymer Based on Silole-Containing Polythiophenes and 2,1,3-Benzothiadiazole. J. Am. Chem. Soc. 2008, 130, 16144-16145.

43. Amb, C. M.; Chen, S.; Graham, K. R.; Subbiah, J.; Small, C. E.; So, F.; Reynolds, J. R., Dithienogermole As a Fused Electron Donor in Bulk Heterojunction Solar Cells. J. Am. Chem. Soc. 2011, 133, 10062-10065.

44. Usta, H.; Lu, G.; Facchetti, A.; Marks, T. J., Dithienosilole- and Dibenzosilole-Thiophene Copolymers as Semiconductors for Organic Thin-Film Transistors. $J$. Am. Chem. Soc. 2006, 128, 9034-9035.

45. Scharber, M. C.; Koppe, M.; Gao, J.; Cordella, F.; Loi, M. A.; Denk, P.; Morana, M.; Egelhaaf, H.-J.; Forberich, K.; Dennler, G.; Gaudiana, R.; Waller, D.; Zhu, Z.; Shi, X.; Brabec, C. J., Influence of the Bridging Atom on the Performance of a Low-Bandgap Bulk Heterojunction Solar Cell. Adv. Mater. 2010, 22, 367-370.

46. Lu, G.; Usta, H.; Risko, C.; Wang, L.; Facchetti, A.; Ratner, M. A.; Marks, T. J., Synthesis, Characterization, and Transistor Response of Semiconducting Silole Polymers with Substantial Hole Mobility and Air Stability. Experiment and Theory. J. Am. Chem. Soc. 2008, 130, 7670-7685.

47. Linshoeft, J.; Baum, E. J.; Hussain, A.; Gates, P. J.; Näther, C.; Staubitz, A., Highly TinSelective Stille Coupling: Synthesis of a Polymer Containing a Stannole in the Main Chain. Angew. Chem. Int. Ed. 2014, 53, 12916-12920.

48. $\quad$ Linshoeft, J.; Baum, E. J.; Hussain, A.; Gates, P. J.; Näther, C.; Staubitz, A., Hoch Zinnselektive Stille-Kupplung: Polymersynthese mit einem Stannol in der Hauptkette. Angew. Chem. 2014, 126, 13130-13134. 
49. Yamaguchi, S.; Tamao, K., Theoretical Study of the Electronic Structure of 2,2'-Bisilole in Comparison with 1, $1^{\prime}$-Bi-1,3-cyclopentadiene: $\sigma^{*}-\pi^{*}$ Conjugation and a Low-Lying LUMO as the Origin of the Unusual Optical Properties of 3,3',4,4'-Tetraphenyl-2,2'-bisilole. Bull. Chem. Soc. Jpn. 1996, 69, $2327-2334$.

50. Mullin, J. L.; Tracy, H. J., Aggregation-Induced Emission in Group 14 Metalloles (Siloles, Germoles, and Stannoles): Spectroscopic Considerations, Substituent Effects, and Applications. In Aggregation-Induced Emission: Fundamentals and Applications, Volumes 1 and 2, John Wiley and Sons Ltd: 2013; pp 39-60.

51. Grolleau, J.; Frère, P.; Gohier, F., Clean and Efficient Iodination of Thiophene Derivatives. Synthesis 2015, 47, 3901-3906.

52. Fadhel, O.; Gras, M.; Lemaitre, N.; Deborde, V.; Hissler, M.; Geffroy, B.; Réau, R., Tunable Organophosphorus Dopants for Bright White Organic Light-Emitting Diodes with Simple Structures. Adv. Mater. 2009, 21, 1261-1265.

53. D. Miles, T. B., A. Lough, D. Foucher, Wurtz Coupling of Perfluorinated Dichlorostannanes. J. Inorg. and Organomet. Polym. 2010, 20, 544-553.

54. Vedejs, E.; Erdman, D. E.; Powell, D. R., Cyclic organotin Lewis acids. J. Org. Chem. 1993, 58, 2840-2845.

55. Rosenthal, U.; Ohff, A.; Baumann, W.; Tillack, A.; Görls, H.; Burlakov, V. V.; Shur, V. B., Struktur, Eigenschaften und NMR-spektroskopische Charakterisierung von $\mathrm{Cp}_{2} \mathrm{Zr}$ (Pyridin)( $\left.\mathrm{Me}_{3} \mathrm{SiC}=\mathrm{CSiMe} 3\right)$. Z. Anorg. Allg. Chem. 1995, 621, 77-83.

56. Linshoeft, J., Rosenthal's Zirconocene. Synlett 2015, 25, 2671-2672.

57. J. R. Nitschke; S. Zürcher; Tilley., T. D., New Zirconocene-Coupling Route to Large, Functionalized Macrocycles. J. Am. Chem. Soc. 2000, 122, 10345.

58. Airapetyan, D. V.; Petrosyan, V. S.; Gruener, S. V.; Zaitsev, K. V.; Arkhipov, D. E.; Korlyukov, A. A., Disproportionation reactions within the series of coordinated monoorganostannanes. J. Organomet. Chem. 2013, 747, 241-248.

59. Portnyagin, I. A.; Lunin, V. V.; Nechaev, M. S., Reverse Kocheshkov reaction Redistribution reactions between $\mathrm{RSn}\left(\mathrm{OCH}_{2} \mathrm{CH}_{2} \mathrm{NMe}_{2}\right)_{2} \mathrm{Cl}(\mathrm{R}=\mathrm{Alk}, \mathrm{Ar})$ and $\mathrm{PhSnCl}$ : Experimental and DFT study. J. Organomet. Chem. 2008, 693, 3847-3850.

60. Bredas, J.; Silbey, R.; Boudreaux, D.; Chance, R., Chain-length dependence of electronic and electrochemical properties of conjugated systems: polyacetylene, polyphenylene, polythiophene, and polypyrrole. J. Am. Chem. Soc. 1983, 105, 6555-6559.

61. Frisch, M. J.; Trucks, G. W.; Schlegel, H. B.; Scuseria, G. E.; Robb, M. A.; Cheeseman, J. R.; Scalmani, G.; Barone, V.; Petersson, G. A.; Nakatsuji, H.; Li, X.; Caricato, M.; Marenich, A.; Bloino, J.; Janesko, B. G.; Gomperts, R.; Mennucci, B.; Hratchian, H. P.; Ortiz, J. V.; Izmaylov, A. F.; Sonnenberg, J. L.; Williams-Young, D.; Ding, F.; Lipparini, F.; F. Egidi; Goings, J.; Peng, B.; Petrone, A.; Henderson, T.; Ranasinghe, D.; Zakrzewski, V. G.; Gao, J.; Rega, N.; Zheng, G.; Liang, W.; Hada, M.; Ehara, M.; Toyota, K.; Fukuda, R.; Hasegawa, J.; Ishida, M.; Nakajima, T.; Honda, Y.; Kitao, O.; Nakai, H.; Vreven, T.; Throssell, K.; J. A. Montgomery, J.; Peralta, J. E.; Ogliaro, F.; Bearpark, M.; Heyd, J. J.; Brothers, E.; Kudin, K. N.; Staroverov, V. N.; T. Keith, R. K.; Normand, J.; Raghavachari, K.; Rendell, A.; Burant, J. C.; Iyengar, S. S.; Tomasi, J.; Cossi, M.; Millam, J. M.; Klene, M.; Adamo, C.; Cammi, R.; Ochterski, J. W.; Martin, R. L.; Morokuma, K.; Farkas, O.; Foresman, J. B.; Fox, D. J. Gaussian 09, Revision D.01, 2016.

62. Dunning, T. H.; Jr.; Hay, P. J., Modern Theoretical Chemistry. Schaefer, H. F.; III, Eds. Plenum: New York, 1977; Vol. 3, pp 1-28. 
63. Hay, P. J.; Wadt, W. R., Ab initio effective core potentials for molecular calculations potentials for the transition-metal atoms Sc to Hg. J. Chem. Phys. 1985, 82, 270-283.

64. Hay, P. J.; Wadt, W. R., Ab initio effective core potentials for molecular calculations potentials for $\mathrm{K}$ to $\mathrm{Au}$ including the outermost core orbitals. J. Chem. Phys. 1985, 82, 299-310. 65. Wadt, W. R.; Hay, P. J., Ab initio effective core potentials for molecular calculations potentials for main group elements Na to Bi. J. Chem. Phys. 1985, 82, 284-298.

66. Davies, A. G.; Gielen, M.; Pannell, K. H.; Tiekink, E. R. T.; Editors, Tin Chemistry; Fundamentals, Frontiers, and Applications. John Wiley \& Sons Ltd.: 2008; p 729 pp.

67. Schleyer, P. v. R.; Maerker, C.; Dransfeld, A.; Jiao, H.; van Eikema Hommes, N. J. R., Nucleus-Independent Chemical Shifts: A Simple and Efficient Aromaticity Probe. J. Am. Chem. Soc. 1996, 118, 6317-6318.

68. $\quad$ von Ragué Schleyer, P.; Manoharan, M.; Wang, Z.-X.; Kiran, B.; Jiao, H.; Puchta, R.; van Eikema Hommes, N. J. R., Dissected Nucleus-Independent Chemical Shift Analysis of $\pi$ Aromaticity and Antiaromaticity. Org. Lett. 2001, 3, 2465-2468.

69. Goldfuss, B.; Schleyer, P. v. R., Aromaticity in Group 14 Metalloles: Structural, Energetic, and Magnetic Criteria. Organometallics 1997, 16, 1543-1552.

70. Sheldrick, G. M., A short history of SHELX. Acta Cryst. 2008, A64, 112-122.

71. Farrugia, L. J., WinGX suite for small-molecule single-crystal crystallograph. J. Appl. Crystalogr. 1999, 32, 837-838.

72. Brandenburg, K. DIAMOND, version 3.2i,; Crystal Impact GbR: Bonn Germany, 2012. 


\section{SYNOPSIS}

For Table of Contents Only

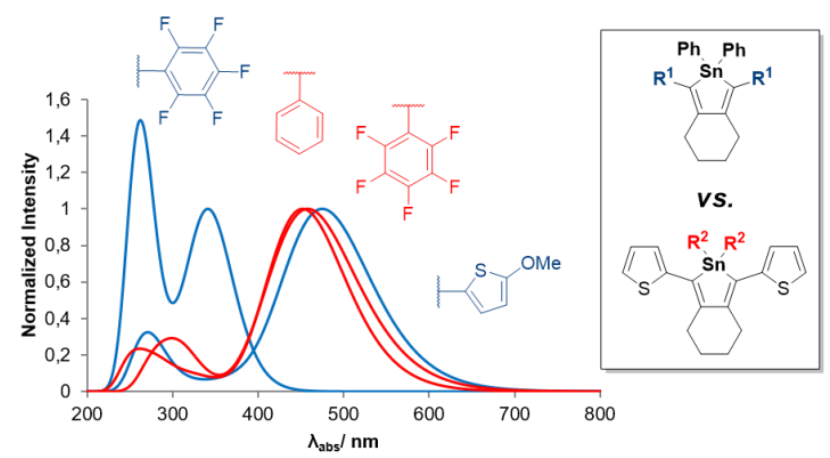

For Synopsis Only

Stannoles are capable of $\sigma^{*}-\pi^{*}$-conjugation. This means that the substituents on the tin atom can also be involved in the electron delocalization of the $\pi$-system or extended $\pi$-system of the stannole ring. This work analyses the contributions of $\pi$-system vs. $\sigma^{*}-\pi^{*}$ contributions computationally and experimentally. 